\title{
Problem-Based Learning in the Field for Schools in Hong Kong : PBL Programs in Kowloon Technical School
}

\author{
CHAN Lung Sang, Associate Professor, \\ Department of Earth Sciences, \\ University of Hong Kong
}

HO Wing Tze, Teacher Librarian, Kowloon Technical School, Hong Kong

\begin{abstract}
The future development of Hong Kong owes a radical change in our current education curriculum. Modern views of learning argue that the conventional instruction mode of science curriculum should shift from a transmission approach to a constructivist approach through Problem-based learning (PBL). This is a radically different pedagogical strategy of posing significant, real world situations and providing resources, instruction to learners. The field is an ideal setting for conducting Problem-based learning because field problems are those authentic but often referred to as ill-structured. They are innately challenging in part because of no definitive or simple answers, thus require a full integration of knowledge across disciplines in the problem solving process. It is believed that students working collaboratively as a PBL group will benefit through repeated goal setting, planning, acting, sharing, reflecting, rethinking and refining. Kowloon Technical School has put into practice two PBL programs for S.6 and S.2 students with the support of the Department of Earth Sciences, the University of Hong Kong through her pioneering project, the "Problem-Based Learning in the Field".
\end{abstract}

\section{Background of the project}

An ultimate goal of education in the Information Literacy Age is commonly agreed by most educators as transforming students into progressive problem solvers and authentic knowledge builders. Most reports, such as the SCANS (Survey of 
Necessary and Comprehensive Skills and Goals 2000) documents in the United States support this argument. Most school goal statements allude to the need for critical thinking and problem solving skills. Nevertheless very often such instruction in problem solving takes the approach of teaching models to students that apply to neat case studies rather than the messy real world problems. A methodology which authentically addresses the core of a problem-solving dominated learning mechanism is imperative.

The need to establish such student-centered problem-solving skills as the primary education goal is also well recognized for Hong Kong students. The recent education reform (Curriculum Development Council, 2001) consultancy report has identified 'Learning to Learn' as the key to the success of our future students. However, this initiative is not as well appreciated by some teachers in Hong Kong due to the lack of demonstrative cases and training programs on problem-solving learning. The Department of Earth Sciences of the University of Hong Kong (HKU) believes the procurement for such a pedagogical change cannot rely solely on the self-initiation of teachers, and must require participation of the tertiary institutions in Hong Kong. A sizeable fraction of courses in the tertiary institutions in Hong Kong are now taught with a problem-solving learning approach including Medicine at HKU. An effort to adopt a similar teaching pedagogy in secondary school, even experimental in nature for the time being, should be encouraged. Successful experience with PBL in the tertiary institute should be shared with secondary school sectors through training workshops for school teachers and organized activities for students on problem-solving dominated learning.

The ideal setting for conducting PBL is in the field, where students are required to cope with real problems, often with no definitive solutions. The field-mapping program in the Department of Earth Sciences, for example, demands students to identify geological units which are often messy and ambiguous, and make judgment on enigmatic situations which cannot be answered in a definitive manner. Such field study, with emphasis on the problem-solving processes rather than the answers to the problems, is cognate with problem-based learning and represents a best means of introducing PBL to school education. Thus, the Department has requested support from the Quality Education Fund (QEF) to undertake training workshops for teachers on problem-based learning in the field setting. The Department has selected Earth Science as the theme of the project because of its nature as a field-based science. In addition, Earth Science has been reported to be the weakest area for Hong Kong students in a recent international study (TIMSS-R, 1999). This current project can 
also enhance the Earth Science component in the school curriculum.

\section{Underlying principles of PBL}

PBL is a pedagogical strategy for posing significant, contextualized, real world situations and providing resources, guidance, and instruction to learners (Mayo, Donnelly, Nash, \& Schwartz, 1993). What significantly distinguishes PBL from other traditional learning mechanisms lies on a coherent component in PBL that participants construct knowledge progressively through neutralizing contextualized problem sets and situations, with neither conventionally practiced classroom-format lectures nor 'end-of-chapter' questions. PBL is a radically different approach to the current mode of teaching-and-learning which constantly needs encouragement and support (White, 1996).

\section{Brief history of PBL development}

In the early 1970s, the concept of PBL was shaped by Dr. Howard Barrows and Ann Kelson of Southern Illinois University, School of Medicine as a curriculum and a process. McMaster University Medical School in Canada was the first to bring PBL to the forefront of education. Of all teaching methods, PBL is the best studied in a scientific sense. Many medical schools have adopted PBL. Today over $80 \%$ of medical schools and many other professional schools utilize PBL to teach professional cases (Bridges and Hallinger, 1991; Vernon and Blake, 1993). PBL is now used globally in higher education in areas such as schools of health sciences, nursing, dentistry, pharmacy, veterinary medicine, public health, architecture, computing, business, law, engineering, forestry, police science, social work, education and many other professional fields including the earth sciences. Many K-12 schools in the U.S. are also using the PBL methodology.

\section{Project description}

\section{Goals}

The project aims to further engage students' curiosity and improve their quality in a sustainable learning environment and ultimately prepare them to succeed in the $21^{\text {st }}$ century. The goals are formulated around the following major goals to exert positive impact on teaching quality and quality learning atmosphere:

\section{Student level}

1. To prepare students to become progressive problem-solvers, passionate 
learners and authentic knowledge constructors with a realization that learning is an on-going process throughout their lifetime.

2. To engage students in authentic practice of empirical scientific inquiry and foster their development on minds of inquiry for the complexity of scientific problems.

3. To develop students with essential communication skills in the fields of listening and speaking in addition to reading and writing via continuous peer-interaction, cooperative learning and peer-collaboration.

4. To prepare students to think critically and analytically, and develop an ability to find appropriate learning resources in order to solve complex real world problems.

5. To widen students' horizon in the earth and natural sciences through a series of fieldwork-based interdisciplinary investigations.

6. To sharpen students' personalities, enhance their personal growth and develop effective written and verbal communication abilities through continuous collaboration in small heterogeneous study groups.

7. To promote teacher-student relationships through constant mentoring, communication, support and encouragement, and collaborative effort to solve problems and thus enhancing quality learning atmosphere.

\section{Teacher level}

1. To prepare teachers to acquire first-hand experience of a fieldwork-based PBL methodology through participating as co-learners in teacher PBL group.

2. To engage teachers in authentic practice of empirical scientific inquiry and enhance their appreciation for the complexity of scientific problems.

3. To widen teachers' horizon in the earth and natural sciences through a series of fieldwork-based interdisciplinary investigations.

4. To widen teachers learning area by providing heterogeneous teacher PBL groups and joint-school presentation delivered by student PBL group.

5. To foster teachers' professionalism by acting as facilitator for student PBL groups and by directly participating in interdisciplinary PBL.

6. To promote teacher-student relationships through constant mentoring, communication, support and encouragement, and collaborative effort to solve problems and thus enhancing teaching quality.

\section{Education community level}

1. To establish partner-relationship between university and secondary schools, and to provide students with an early on interaction with university staffs 
and thus widen their horizon on various disciplines of studies.

2. To establish a cooperative relationship between private sector and education sector via intervening group discussions with experts-in-the-field.

\section{Objectives}

The following objectives in the domains of cognitive, psychomotor and affective are the specific illustration of the project goals.

\section{Student level}

1. Participating students are able to demonstrate independently the operational procedure of Scientific Inquiry (detailed observation, full description, sampling of data, processing and analysis of data, experimental verification, presentation of findings, formulation of hypotheses, evaluation of inferred results and collaboration with peers).

2. Participating students are able to identify the geosphere, atmosphere, hydrosphere and biosphere as the essential components of the Earth System and realize that the Earth System operates as a function of these parameters which are all complexly inter-related.

3. Participating students are able to demonstrate independently the operational procedure of fieldwork and laboratory research techniques.

4. Participating students are able to utilize a variety of 2-Dimensional graphics techniques such as statistical diagrams, tables, concept maps, flow charts, tree diagrams, labeled photographs and sketches for a systematical organization of information and for a well-constructed presentation of an idea or an event.

5. Participating students are able to utilize their scientific knowledge acquired in PBL to account satisfactorily for some of field problems with a demonstration of interdisciplinary knowledge, such as the impact of seawater salinity on weathering features, the control of soil nutrition and lithology on vegetations growth.

6. Participating students are able to create learning portfolios (encountered difficulties, ways to seek resources, plan for group work and individual work) to record the progress of their group work, individual work and achievement.

7. Participating students are able to demonstrate a willingness to acquire new knowledge and will actively ask questions when they have difficulties.

8. Participating students are able to show the sense of responsibilities to other constituent members in group work such as satisfactory completion of assigned individual task on time, attendance of fieldwork and group 
discussion.

9. Participating students are able to illustrate their commitment to the group work and individual work such as sacrifice of personal spare time for quality group work and individual work.

10. Participating students are able to demonstrate consideration and politeness to other constituent members during collaborative work such as an understanding of varying individual member's background and ability.

\section{Teacher level}

1. Participating teachers are able to establish and coordinate a small-scale and highly self-directed learning community for thematic study within their secondary schools, illustrating the techniques in facilitating, guiding and mentoring the student PBL group.

2. Participating teachers are able to identify the geosphere, atmosphere, hydrosphere and biosphere as the essential components of the Earth System and realize that the Earth System operates as a function of these parameters which are all complexly inter-related.

3. Participating teachers are able to create teaching portfolios (encountered difficulties of conducting self-directed learning community, appropriate ways to give participating students guidelines, ways to engage students' learning motivation, effective teaching strategies and assessment of learning and teaching effectiveness) to record the progress of their group work, individual work and achievement.

\section{Education community level}

1. Participating teachers are able to demonstrate a change in their conceptions and approaches to teaching.

2. Participating teachers are able to incorporate learned strategies into their own school-based curriculum.

3. Participating teachers share ideas and the good practices of the current project with other non-participating teachers from participating or non-participating schools, provoking wider public dissemination.

\section{Targets}

1. The targets are secondary school students ranging from Form 1 to Form 7 students and teachers.

2. The project adopts a voluntary-basis for all participating students. Participating students selected by their teachers are based on their interview 
performance and past overall performance in school.

\begin{tabular}{|c|c|}
\hline Targets & Number \\
\hline Participating secondary schools & 16 \\
\hline Participating teachers & 32 \\
\hline Participating students & 640 \\
\hline
\end{tabular}

\section{Number of beneficiaries}

Beneficiaries can be subdivided into two types: one is the participating students and teachers who directly take part in the proposed project $\left(1^{\text {st }}\right.$ level) while another is those students and teachers who learn fruitful experiences of the proposed project from participating students and teachers via whole-school presentation and exhibition $\left(2^{\text {nd }}\right.$ level). The expected numbers of beneficiaries are tabulated as below:

\begin{tabular}{|c|c|c|}
\hline & Number of beneficiary teachers & Number of beneficiary students \\
\hline $\begin{array}{c}\mathbf{1}^{\text {st }} \text { level } \\
\text { Direct } \\
\text { beneficiaries) }\end{array}$ & $\begin{array}{c}\text { 2 from each participating school } \\
\text { (Total: 32 teachers for 4 rounds) }\end{array}$ & $\begin{array}{c}20 \text { students/teacher } \\
\text { (Total: 640 students for 4 rounds) }\end{array}$ \\
\hline $\begin{array}{c}\text { (Indirect } \\
\text { beneficiaries) }\end{array}$ & All teachers from participating \\
school & $\begin{array}{c}\text { All students (both Arts and Science) } \\
\text { from participating school }\end{array}$ \\
\hline
\end{tabular}

In addition, the entire education sector can benefit from the successful experience of the present project which serves as a reference of pioneering learning methodology mingling field studies, science curriculum and PBL.

\section{Extent of teachers and principals' involvement}

In general, teachers' involvement is a more direct way through direct participation in Phase 1 PBL. Teachers offer a more direct interaction with students through acting as group facilitator while principals offer an essential backup for both teachers and students. 


\section{Teachers' involvement}

Since the project will be run in two phases, roles played by teachers in each phase are remarkably different.

\section{Phase 1}

1. Participating teachers attend the PBL workshop organized by the Faculty of Medicine jointed with the Department of Earth Sciences at HKU.

2. Teachers participate in the Phase $1 \mathrm{PBL}$, undertaking the tasks of Phase 1. Detailed description of tasks is given in next section.

3. Teachers assist dissemination of their successful experience, the ideas and practices of the present project inside school, in the education sector or to the public.

4. Teachers have to work closely with the project team to evaluate the effectiveness of Phase 1 PBL.

\section{Phase 2}

1. Teachers are actively engaged in the design of problems assigned to student PBL groups by identifying students' needs, strengths and weakness.

2. Teachers assist dissemination of the ideas and practices of the present project school among students.

3. Teachers share their experience with other participating teachers from different schools.

4. Teachers act as facilitator/mentor for Phase 2 program.

5. Teachers have to evaluate the effectiveness of Phase 2 by collecting student baseline measurement.

\section{Principals' involvement}

The roles played by principals during the implementation process are less direct than those of teachers. However, principals' involvement is essential to the success of the entire PBL project because:

1. Principals give empower participating teachers in taking up the responsibilities.

2. Principals give full support to both participating teachers and students by allowing a flexible timetable for their group work.

3. Principals adjust participating teachers' workload.

4. Principals minimize the resistance from parents via parents meetings to 
introduce the ideas of the project.

5. Principals assist dissemination on the ideas and practices of the current project in among non-participating students and teachers through various forums or participants sharing session.

\section{The roles for teacher and student in the project}

In our model, traditional teacher and student roles change dramatically as the whole teaching-and-learning mechanism remarkably shifts from a teacher-centered system to a student-centered one. With great reduction on the amount of direct instruction, students assume increasing responsibility for their own learning (Bridges \& Hallinger, 1991), giving them more motivation and a sense of accomplishment, leading them to become successful life-long learners and progressive problem-solvers. The teaching organizations and individual teachers in turn become facilitator, tutors, evaluators and task group consultants rather than information-provider or expert.

\section{Implementation plan}

\section{Programs and activities}

The project runs four rounds over a 28-month-period. Each round is intentionally subdivided into two main phases. Phase 1 is targeted at teachers and Phase 2 at students. The two phases are designed slightly differently due to the different capability and attitude of teachers and students, for example teachers needed first-hand experience of field-based PBL and students benefit from being introduced to a collaborative work in field setting.

\section{Main components of Phase 1 and Phase 2}

Phase 1 and Phase 2 are conducted in a similar fashion, comprising of three major components: PBL workshop, Action research and Interaction with experts-in-the-field. Table 1 below delineates the tasks and characteristics of phase 1 and 2.

\section{PBL workshops}

A weekend field camp is organized for teachers in the first Phase of the programmed. The field camp starts off with a workshop on PBL. An expert on the subject is invited to give an overview of the concept and principles behind the learning pedagogy. The participants are divided into groups and undertake an action research on a specific problem using the PBL approach. The camp 
culminates in a summary session to discuss problems how to overcome problems encountered in PBL and how to conduct PBL in the field for students.

\section{Action research}

“Action research" basically consists of five main stages: cognition (identifying), planning (strategies formulation), process and analysis (verification of collected raw data), presentation of findings (verbal presentation and exhibition) and final assessment of the project impact. The groups are also advised that in the process of PBL, they may sometimes have to revisit a particular stage, make modifications and repeat the second stage in an iterative manner. Towards the end of the fieldcamp, participating teachers spend 2 hours come together in a discussion session. The discussion focuses on problem resolution of PBL challenges and how to implement a PBL field camp for their students.

\section{Interaction with experts-in-the-field}

Experts in relevant fields interact with PBL group members as part of the action research such that participating students can acquire a general picture of what they plan to research. During these discussions with experts, all participating students are encouraged to utilize the opportunity to explore how the classroom-teaching materials are applied in the real world. 


\begin{tabular}{|c|c|c|c|c|}
\hline Stage & Teacher roles & Strategies/goals & Student roles & Strategies/tasks \\
\hline Cognition & $\begin{array}{c}\text { Facilitator } \\
\text { Mentor } \\
\text { Guide }\end{array}$ & 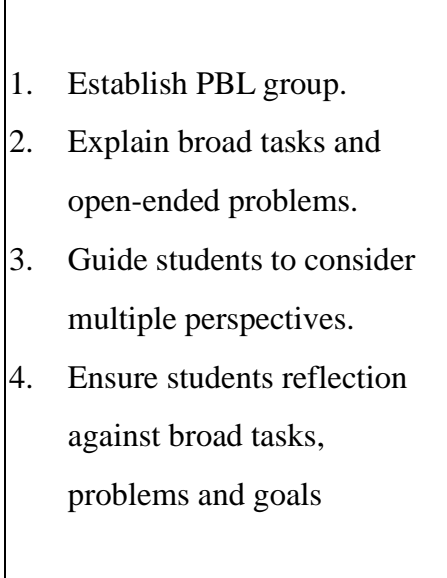 & $\begin{array}{c}\text { Problem } \\
\text { Solver } \\
\text { Collaborator }\end{array}$ & 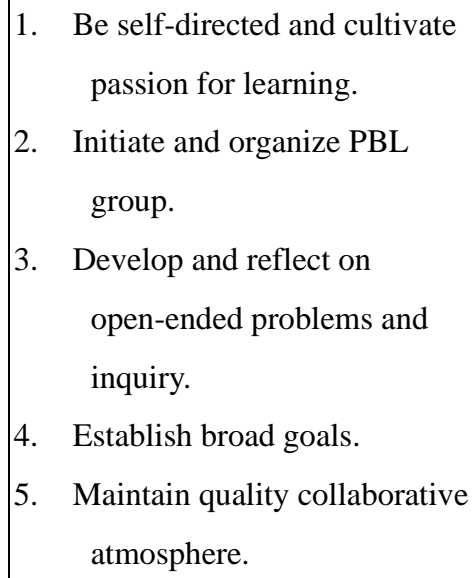 \\
\hline Planning & $\begin{array}{c}\text { Facilitator } \\
\text { Mentor } \\
\text { Guide }\end{array}$ & 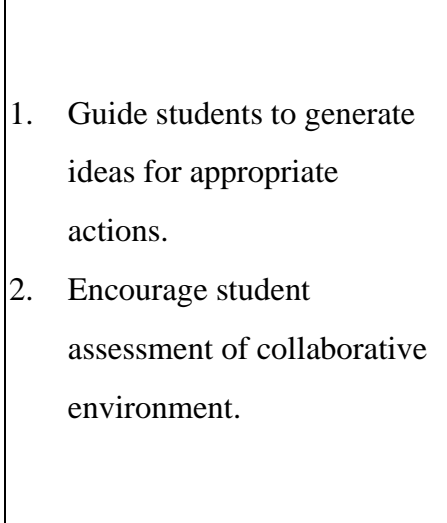 & $\begin{array}{c}\text { Problem } \\
\text { Solver } \\
\text { Collaborator }\end{array}$ & $\begin{array}{ll}\text { 1. } & \text { Formulate different } \\
& \text { perspectives, theories and } \\
& \text { hypotheses. } \\
\text { 2. } & \text { Consider alternative solutions } \\
\text { 3. } & \text { Refine according to feedback } \\
\text { from teachers and peers } \\
\text { 4. } & \text { Interact with peers, teachers, } \\
\text { local officials and } \\
\text { experts-in-the-field }\end{array}$ \\
\hline $\begin{array}{c}\text { Process and } \\
\text { analysis }\end{array}$ & $\begin{array}{c}\text { Facilitator } \\
\text { Mentor } \\
\text { Guide }\end{array}$ & $\begin{array}{ll}\text { 1. } & \text { Monitor progress of group } \\
& \text { work. } \\
\text { 2. } & \text { Help students develop } \\
& \text { hypotheses. } \\
\text { 3. } & \text { Verify goals set out } \\
& \text { previously. } \\
\text { 4. } & \text { Assist fieldwork and } \\
& \text { coordinate logistics. } \\
\text { 5. } & \text { Anticipate new needs for } \\
& \text { group. }\end{array}$ & $\begin{array}{c}\text { Problem } \\
\text { Solver } \\
\text { Collaborator } \\
\text { Evaluator }\end{array}$ & $\begin{array}{ll}\text { 1. } & \text { Formulate hypotheses as } \\
& \text { sketches, notes and drafts. } \\
\text { 2. } & \text { Undertake fieldwork actively. } \\
\text { 3. } & \text { Maintain quality collaborative } \\
\text { environment } \\
\text { 4. } & \text { Modify, evaluate and refine } \\
\text { previous reflection if } \\
\text { necessary. } \\
\text { 5. }\end{array}$ \\
\hline $\begin{array}{l}\text { Presentation } \\
\text { on findings }\end{array}$ & $\begin{array}{c}\text { Facilitator } \\
\text { Mentor }\end{array}$ & $\begin{array}{ll}\text { 1. } & \text { Monitor presentation } \\
& \text { rehearsals. } \\
\text { 2. } & \text { Monitor outputs for quality. }\end{array}$ & $\begin{array}{c}\text { Problem } \\
\text { Solver } \\
\text { Collaborator } \\
\text { Evaluator } \\
\text { Teacher }\end{array}$ & $\begin{array}{ll}\text { 1. } & \text { Synthesize and finalize } \\
& \text { findings } \\
\text { 2. } & \text { Undertake extra data } \\
& \text { collection if necessary. } \\
\text { 3. } & \text { Review critically outputs. } \\
\text { 4. } & \text { Construct outputs and } \\
& \text { presentation. }\end{array}$ \\
\hline $\begin{array}{c}\text { Final } \\
\text { assessment }\end{array}$ & $\begin{array}{c}\text { Facilitator } \\
\text { Mentor }\end{array}$ & $\begin{array}{l}\text { 1. Act as observer. } \\
\text { 2. Encourage students to teach } \\
\text { others in informal and } \\
\text { formal contexts. } \\
\text { 3. Gather feedback from the } \\
\text { floor. }\end{array}$ & $\begin{array}{c}\text { Evaluator } \\
\text { Teacher }\end{array}$ & $\begin{array}{l}\text { 1. Teach others in informal and } \\
\text { formal contexts. } \\
\text { 2. Gather and reflect feedback } \\
\text { from the floor. } \\
\text { 3. Peer conference with } \\
\text { peer-evaluation. } \\
\text { 4. Discuss how to improve. }\end{array}$ \\
\hline
\end{tabular}


Table 1: Action research plan (Phase 2) - tasks tackled by teachers and students during different stages (Note: Participating teachers in Phase 1 will undertake the roles played by participating students in Phase 2 as shown above.)

Student PBL group complete written and verbal reports for whole-school presentation on their findings with a set of well-prepared visual aids. They also present to one other participating school. Groups also complete a poster exhibition and all participating students produce portfolio reflecting on their experience. Each teacher PBL group complete a report and verbal presentation with visual aids. Teachers produce a teaching portfolio and PBL workshop materials are be produced. Parents are well informed of goals and outcomes of the project and materials are produced on CD-ROM.

Expected outcomes guide the project for students, teachers and the community. Learning to learn is at the center as well as interdisciplinary study, scientific method and authentic assessment.

\section{Evaluation parameters and method}

The study emphasized the need to evaluate the effectiveness of the project. The first phase fosters the teacher development on the practice of PBL. Participants are well equipped with the skills of acting PBL facilitator, provided with the first-hand experience of fieldwork-based PBL. The second phase fosters student development through the fieldwork-based PBL.

The evaluation consists of quantifiable measures of the deliverables, an independent assessor who conducts the evaluation and interviews, and furnishes an independent report that will be submitted along with the final report of the proposal. Participating teachers complete an evaluation through questionnaires and in-depth interviews. Evaluation from students. All participating students submit an evaluation for the project and undertake peer-evaluation. A selected group of students is invited to an assessment session and present verbal comments on the project.

\section{PBL Programs in Kowloon Technical School}

\section{Using Problem-based Learning (PBL) approach in designing learning activities in "Adventuring to Learn" for Sixth Formers}

As one of the schools participating, the Adventure-Ship Project was developed so 
students would learn about sailing and survival skills. The program organizers also sought to enhance the students' ability to solve problems, work collaboratively with others and raise their self-esteem. A focus for study: the "Water Quality of Hong Kong Waters" was chosen because students had some background knowledge about water pollution and would have an opportunity to collect data and information about water quality during the trip. The program was supported by Dr. Chan Lung San, Associate Professor of the Department of Earth Sciences, the University of Hong Kong who with the PBL helped design the learning activities. Structure was provided in a problem statement, scaffolding students search for facts and ideas and formulating hypotheses and the learning issues. The project proceeded from October to November 2004.

An action plan helped students with the PBL process to include reading the problem statement, finding the facts \& ideas, setting possible hypotheses, rearranging the hypotheses, deciding the learning issues, formulating the working procedures. Students developed the action plan as part of an iterative process and even designed and made their own equipments.

Students collected water samples and data at different sites. They observed the surrounding, took pictures, did experiments and recorded data. Teachers supervised students on their work and reminded them the possible errors they could make and guided them to look for solution.

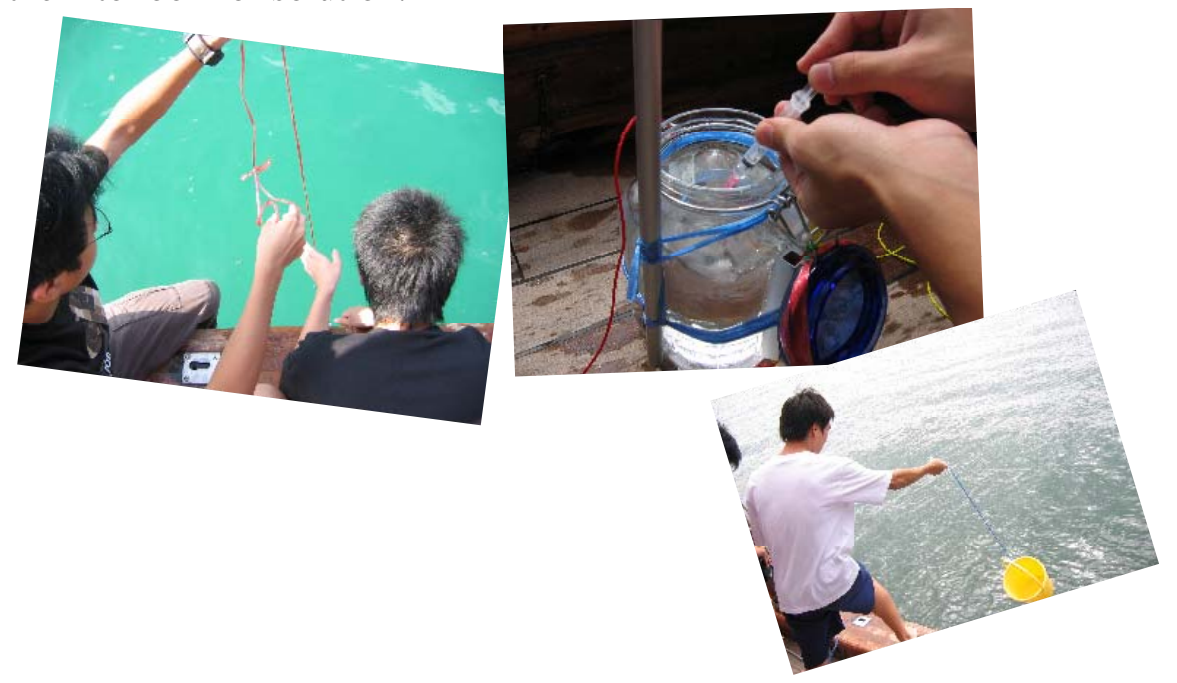

Students carried out a series of experiments with the water samples they collected. The experiments included finding out the amount of dissolved oxygen at different sites, and recording the number of e-coil on paper. Then they analyzed the results, drew their conclusion and finally made up a report. They then presented their report to 
their fellow students in school as well as to the public in the Quality Education Fund Projects Exposition 2005.

\section{Observations}

Students were motivated in learning. The training on the ship could enhance their sense of responsibility, team work and communication skills and raise their self-esteem. It contributed to social responsibility in protecting the environment. Improvements could be made: facilitators would have been good assistance to teams especially in the preparation phase. Students reported that the project was effective in helping build critical thinking. It forced them to think about learning differently as they noted PBL was time-consuming and it was not easy to do the peer-assessment.

\section{Using Problem-based Learning (PBL) approach in designing learning activities for Second Formers}

For S.2 students, the program was integrated into the subject Life Education. A real life problem unique to Shumshuipo, the district in which most of the students live was developed. Students could choose among three problem statements. The program proceeded from March to May 2005 and was also supported by input from the University of Hong Kong partners.
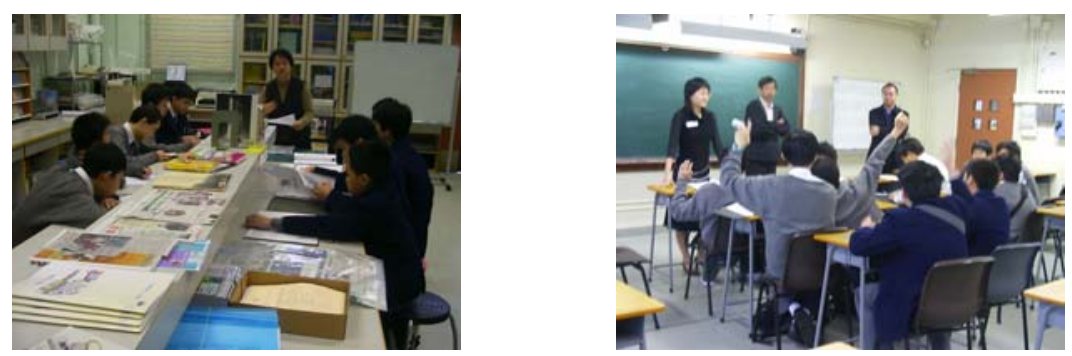

A group of students was working in the school library while another group was discussing their problem with their facilitators and an expert from HKU.

\section{Conclusion}

As evidenced by literature on PBL and the positive experience of two PBL projects at Kowloon Technical School, the participants in this study observed that PBL is an effective approach to teaching and learning. It can enhance the learning environment, helping students “learn to learn” while developing problem solving skills and self-directedness The process can trigger peer-inspiration among other 
non-participating students in participating schools.

As well, the teacher-student relationship will be further promoted through constant mentoring, encouragement and communication and thus enable a quality learning environment. Teaching is improved as teachers enhance skills in self-directed learning. The metacognitive character of the project makes it sustainable as well as providing reference and teaching materials for students and teachers. The project also has as a goal to widely disseminate information about the outcomes to the broader community and stakeholders. 


\title{
References
}

Bridges, E. M., \& Hallinger, P. (1991, September). Problem-based learning in medical and managerial education. Paper presented for the Cognition and School Leadership Conference of the National Center for Educational Leadership and the Ontario Institute for Studies in Education, Nashville, TN.

Mayo, P., Donnelly, M. B., Nash, P. P., \& Schwartz, R. W. (1993). Student perceptions of tutor effectiveness in problem based surgery clerkship. Teaching and Learning in Medicine. 5(4), 227-233.

Vernon, D. T., \& Blake, R. L. (1993). Does problem-based learning work? A meta-analysis of evaluative research. Academic Medicine, 68(7) 550-563.

White, H. B. (1996). UD PBL: Dan Tries Problem-Based Learning: A Case Study. Retrieved June 1, 2005 from http://www.udel.edu/pbl/dancase3.html

\author{
Kowloon Technical School
}

\section{Appendix A}

\section{乘風航全方位學習行動計劃書 (For students)}

(Action Plan for the Adventure Trip - Academic Section)

1. 議題描述 (Problem statement)

中新網 2004 年 09 月 07 日

\section{維多利亞港受紅潮侵襲 所發現藻類不含毒素}

據香港星島日報報道, 香港維多利亞港昨日出現大面積的紅潮, 長度達十二

公里，顯示維港水質污染仍然嚴重，改善水質的工作刻不容緩。 
報道稱，繼日前香港多個養魚區出現紅潮，殺死了千擔活魚後，紅潮昨日 擴散至維港水域，令維港忽然泛起一片紅。香港特區政府發言人指，昨日收到 維港水域發現紅潮的報告，而特區政府跨部門紅潮工作小組及漁護署亦即在將 軍澳至銅鑼灣一帶，長達十二公里的水域，收集水辦化驗。香港特區政府發言 人強調，香港每年都會出現紅潮，而維港出現紅潮亦非首次。她指出，紅潮在 出現後，一般都會在短時間內消散，所以市民母須恐慌，至於昨日在維港出現 的紅潮，初步證實是香港常見的海洋原甲藻，不含毒素。

紅潮是由單細胞的藻類形成, 水溫十八至二十五度、水流緩慢, 鹽度不太 高及有營養物的水域是最適合紅潮生長。上星期，香港特區政府跨部門紅潮工 作小組便收到五宗紅潮報告，紅潮更令沙頭角、吉澳及塔門一帶的養魚大批死 亡，損失慘重。

香港公開大學環境學系主任何建宗指出, 雖然每年的三月至五月、十月及 十一月才是紅潮出現的季節, 但由於早前持續大雨, 相信引發紅潮提早出現。他 希望特區政府加大力度推行海港淨化計劃，防止紅潮問題惡化。

2. 組員名單 (Member list) $* * *$ 組長

\begin{tabular}{|l|l|l|}
\hline 姓名 (Names) & 班別(Class) & 學號(Class Number) \\
\hline & & \\
\hline & & \\
\hline & & \\
\hline
\end{tabular}




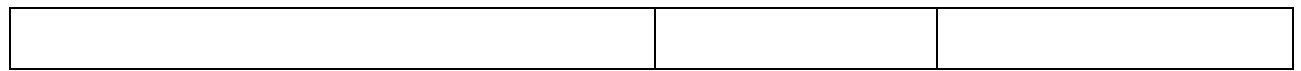

3. 事實與意見 (Facts \& Ideas)

\begin{tabular}{|l|l|}
\hline 事實(Facts) & 意見 ( Ideas) \\
\hline & \\
\hline & \\
\hline & \\
\hline & \\
\hline
\end{tabular}

4. a. 擬定假設 (Setting Hypotheses)

\begin{tabular}{|l|}
\hline 2 \\
\hline 2 \\
\hline 2 \\
\hline 2
\end{tabular}

b. 重組及排列重要先後次序 (Rearrange the hypotheses according their importance)

\begin{tabular}{|l|l|}
\hline 1 & \\
\hline 2 & \\
\hline 3 & \\
\hline
\end{tabular}




\begin{tabular}{|l|l|}
\hline 4 & -2 \\
\hline 5 & \\
\hline
\end{tabular}

\section{5. 探討問題 (Learning Issues)}

\begin{tabular}{|l|}
\hline \\
\hline \\
\hline \\
\hline \\
\hline
\end{tabular}

\section{6. 行動計劃 (Action Plan)}

\begin{tabular}{|c|c|c|c|c|}
\hline \multicolumn{1}{|c|}{$\begin{array}{c}\text { 探討問題 } \\
\text { (Learning Issues) }\end{array}$} & $\begin{array}{c}\text { 搜集何類資料 } \\
\text { (What types of data } \\
\text { to be collected) }\end{array}$ & $\begin{array}{c}\text { 搜集方法 } \\
\text { (Methods of } \\
\text { collection) }\end{array}$ & $\begin{array}{c}\text { 所需物品 } \\
\text { (Equipments } \\
\text { required) }\end{array}$ \\
\hline 1 & & & & \\
\hline 2 & & & & \\
\hline 3 & & & & \\
\hline 4 & & & & \\
\hline 5 & & & & \\
\hline
\end{tabular}

7. 擬取樣本地點 (Data collection sites)

\begin{tabular}{|c|c|c|c|c|c|}
\hline $\begin{array}{c}\text { 位置 } \\
\text { (Location) }\end{array}$ & 1 & 2 & 3 & 4 & 5 \\
\hline
\end{tabular}




\begin{tabular}{|c|l|l|l|l|l|}
\hline 格網座標 & & & & \\
(Grid reference) & & & & & \\
\hline
\end{tabular}

- 格網座標 (6 位數字) - 先讀取垂直的東行線數字, 然後再讀取水平的北 行線數字

8. 數據紀錄表格 (Data Record Form)

\begin{tabular}{|l|l|l|l|l|}
\hline & & & & \\
\hline & & & & \\
\hline & & & & \\
\hline & & & & \\
\hline & & & & \\
\hline
\end{tabular}

9. 對乘風航全方位學習工作坊的感受 (Comments of the trip)

\begin{tabular}{|l|l|}
\hline Names & \multicolumn{1}{c|}{ Comments } \\
\hline & \\
\hline & \\
\hline & \\
\hline & \\
\hline & \\
\hline
\end{tabular}

請將計劃書經本校內聯網電郵給譚國新老師、葉柏麟老師, 張國興老師及林鳳琼 老師。

Please send your proposed action plan to Mr. Tam KS, Mr. Ip PL, Mr. Cheung KH and 
Ms. Lam FK through the School Intranet. 
(For teachers only)

3. 事實與意見 (Facts \& Ideas)

\begin{tabular}{|l|l|}
\hline \multicolumn{1}{|c|}{ Facts (事實) } & \multicolumn{1}{|c|}{ Ideas (意見) } \\
\hline 香港維多利亞港昨日出現大面積的紅 & 維港水質污染仍然嚴重，改善水質的工 \\
潮，長度達十二公里 & 作刻不容緩 \\
\hline 養魚區出現紅潮，殺死了千擔活魚 & 市民冊須恐慌 \\
\hline 擴散至維港水域 & 但由於早前持續大雨，相信引發紅潮提 \\
\hline 海洋原甲藻，不含毒素 & 早出現 \\
\hline 香港每年都會出現紅潮 & 希望特區政府加大力度推行海港淨化計 \\
\hline 紅潮在出現後，一般都會在短時間內消 & \\
\hline 防止紅潮問題惡化 \\
\hline 沙頭角、吉澳及塔門一帶的養魚大批死 \\
\hline 紅潮是由單細胞的藻類形成，水溫十八 \\
至二十五度、水流緩慢，鹽度不太高及 \\
養物的水域是最合紅潮生長 & \\
\hline & \\
\hline
\end{tabular}

5. 學習領域 (Possible Learning issues) 

a. 港海水質污染程度惡化是政府處理污水的政策不當
b. 港海兩岸城市發展對維港水質做成惡劣的影響
c. 昂船洲污水處理系統對港海的水質只有輕微的改善
d. 政府應賠償漁户在今次紅潮襲港的損失
e. 紅潮的出現並不單是自然現象 


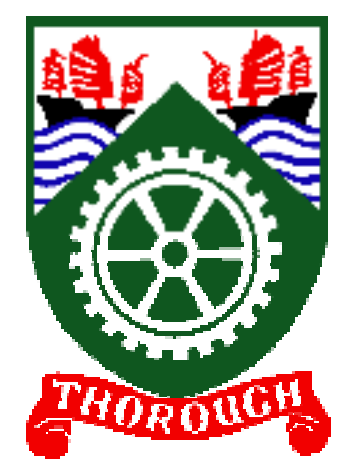

Appendix B

九龍工業學校

問題導向學習

Problem-Based Learning (PBL)

中二年級

專題研習學生手冊

2005 年 3 月 
生命教育科

上課日期表

\begin{tabular}{|c|c|c|c|c|c|c|}
\hline 課堂 & Day 6 & Day 1 & Day 2 & Day 3 & Day 4 & Day 5 \\
\hline 1 & $1 / 3$ & $2 / 3$ & $3 / 3$ & $4 / 3$ & $7 / 3$ & $8 / 3$ \\
\hline 2 & $9 / 3$ & $10 / 3$ & $11 / 3$ & $14 / 3$ & $15 / 3$ & $16 / 3$ \\
\hline 3 & $17 / 3$ & $18 / 3$ & $21 / 3$ & $22 / 3$ & $23 / 3$ & $24 / 3$ \\
\hline 4 & $7 / 4$ & $8 / 4$ & $11 / 4$ & $12 / 4$ & $13 / 4$ & $14 / 4$ \\
\hline 5 & $15 / 4$ & $18 / 4$ & $19 / 4$ & $20 / 4$ & $21 / 4$ & UT \\
\hline 6 & $25 / 4$ & $26 / 4$ & $27 / 4$ & $28 / 4$ & $29 / 4$ & $3 / 5$ \\
\hline 7 & $4 / 5$ & $5 / 5$ & $6 / 5$ & $9 / 5$ & $10 / 5$ & $11 / 5$ \\
\hline 8 & $12 / 5$ & $13 / 5$ & $17 / 5$ & $18 / 5$ & $19 / 5$ & $20 / 5$ \\
\hline 9 & $23 / 5$ & $24 / 5$ & $25 / 5$ & $26 / 5$ & $27 / 5$ & $30 / 5$ \\
\hline
\end{tabular}

UT (Uniform Test 統測)

中二各班上課時間表

\begin{tabular}{|l|c|c|c|c|c|}
\hline Day 6 & Day 1 & Day 2 & Day 3 & Day 4 & Day 5 \\
\hline & & & & & \\
\hline & & & & & 2C \\
\hline & & & & & 2C \\
\hline
\end{tabular}




\begin{tabular}{|l|l|l|l|l|l|}
\hline $2 \mathrm{D}$ & & $2 \mathrm{E}$ & & & \\
\hline $2 \mathrm{D}$ & & $2 \mathrm{E}$ & & & \\
\hline & & & $2 \mathrm{~B}$ & & \\
\hline & & $2 \mathrm{~A}$ & $2 \mathrm{~B}$ & & \\
\hline & & $2 \mathrm{~A}$ & & & \\
\hline
\end{tabular}

老師姓名：

負責班別： 


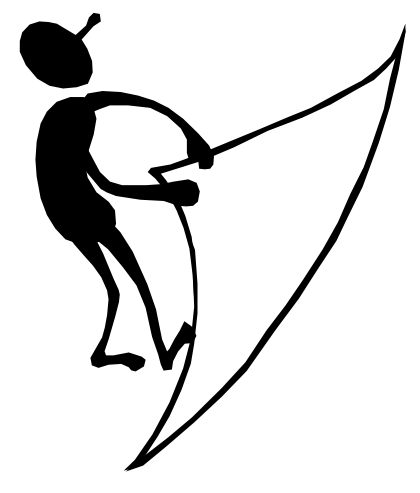

起步禮

日期： 2005 年 2 月 18 日

時間：下午三時

地點：禮堂

程序：

1.「問題導向學習」簡介

2. 分組

3. 彼此認識

4. 建立學習常規及互勉承諾

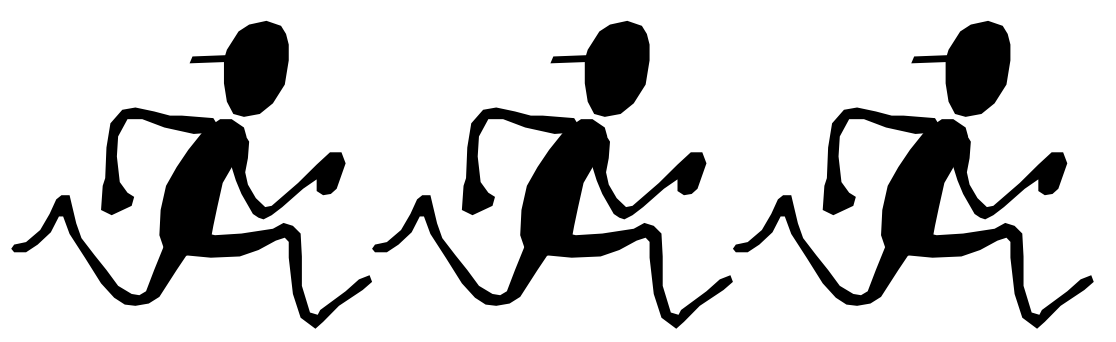


「問題導向學習」簡介

「問題導向學習」Problem-Based Learning (PBL) 是一種突破傳統 的教育策略，其要旨是向同學提出一些真實的、有意義的問題敘述， 並提供資源與指引，引導同學自己尋求解決問題的方法，並判斷各種 解決辦法是否有足夠理據。此學習方法既沒有常規的講課，也沒有千 篇一律的課後習題，卻注重技能與態度的培訓，以幫助同學發現、界 定、調查、了解及評估問題，並提出解決的辦法，使同學從探索和解 決問題的過程中逐漸累積到豐富的知識。其特式為：

1. 以真實生活為框架 (Real-life cases)

2. 跨學科範疇 (Inter-disciplinary)

3. 學生為本 (Student-centred)

同學的角色

1. 主動參與學習歷程

2. 自行決定學習目標

3. 自行設計學習方法

4. 透過分析、整理資料析和報告的過程， 建構知識和經驗

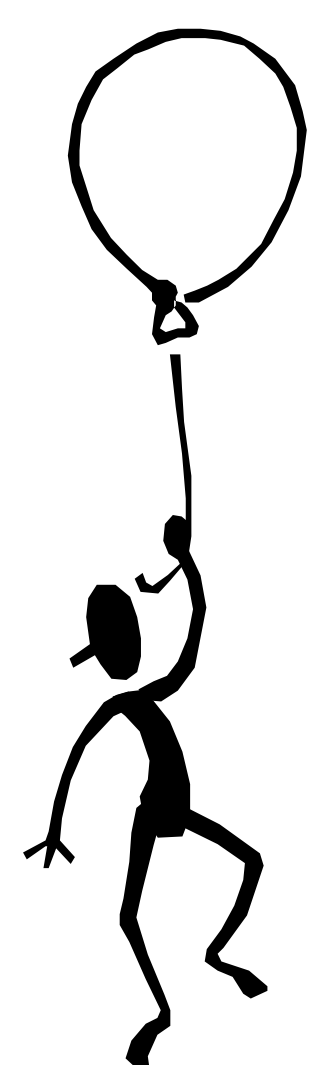


老師的角色

1. 引導而非指導

2. 確保每位同學的參與機會

3. 鼓勵同學自我評鑑

4. 給予同學更大的自由度和發揮空間 
$「$ 問題導向學習」流程圖

\section{面對問題敘述}

(同學透過小組討論分辨問題敘述中的事實和意見/假設，擬定學習目 標及設計研究方法。)

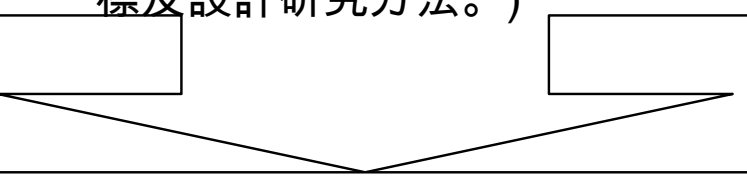

\section{搜集資料}

(闭學搜集、分析及評鑑資料，著重過程的主動參與，溝通及協作。)

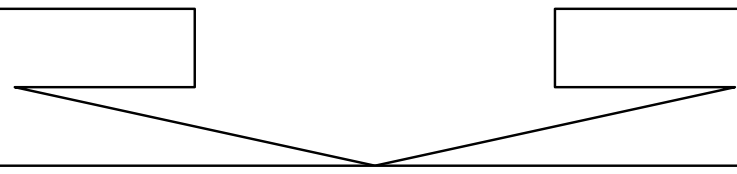

\section{建構解決問題的方法}

(闹學提出初步解決方法，查核及推測方法落實可能產生的後果。)

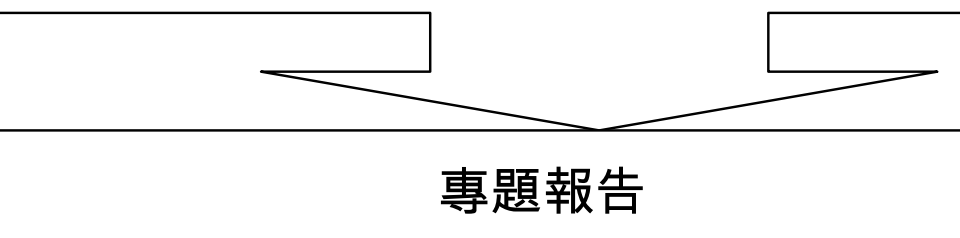

(同學選擇較可取的方法並以合適的形式表達其解決方法。)

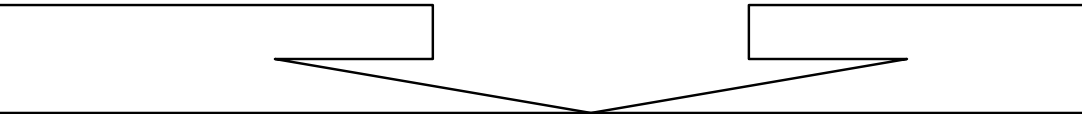

\section{學習總結及反思}

(周學透過自評及互評反思整個「問題導向學習」過程。)

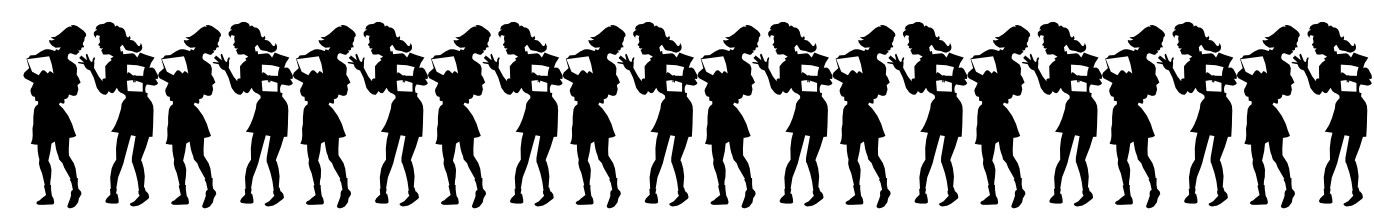


彼此認識

我們的組名是

我們的組員和互勉承諾：

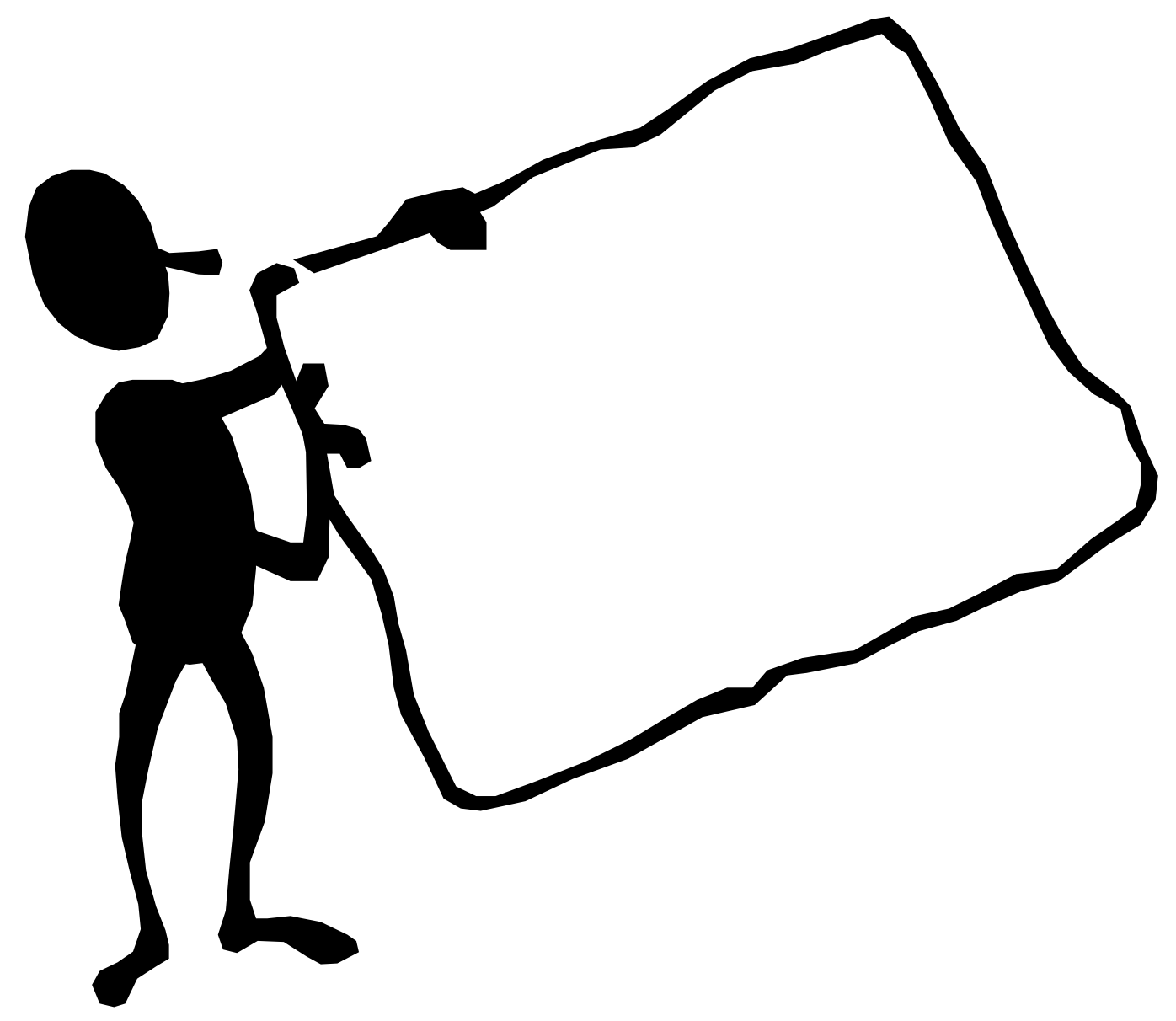

31 


\section{課程大綱}

\begin{tabular}{|c|c|c|c|}
\hline 課堂 & 課題 & 教學重點 & 目的 \\
\hline 1 & 構思主題 & $\begin{array}{l}\text { 1. 展示學兄的專題報告, 讓同學 } \\
\text { 以評審員角度列出優質專題 } \\
\text { 報告的指標 } \\
\text { 2. 讓同學透過檢視 } 「 \text { 專題研習學 } \\
\text { 生手冊」的要點來初步掌握學 } \\
\text { 習的過程 } \\
\text { 3. 讓同學選定 } 「 \text { 問題敘述」, 構 } \\
\text { 思主題及探究有關事實 意見 } \\
\text { /假設、學習目標及行動計劃 } \\
\text { 4. 讓同學以不同角色探討有關 } \\
\text { 「問題敘述」及構思角色要求 }\end{array}$ & $\begin{array}{l}\text { 讓同學掌握專題研習的目 } \\
\text { 的及有效使用 }\ulcorner\text { 專題研習學 } \\
\text { 生手冊」的要點 } \\
\text { 讓同學掌握全腦思考以激 } \\
\text { 發創意 }\end{array}$ \\
\hline 2 & 修定題目 & \begin{tabular}{|l} 
1. 讓同學以 $「$ 心智圖思考法」探 \\
討所定主題的相關題目 \\
2. 讓同學制定研習方法及設定 \\
分工表 \\
3. 與同學設定檢索資料途徑及 \\
取捨資料原則
\end{tabular} & $\begin{array}{l}\text { 讓同學掌握選取資料的方 } \\
\text { 法並培養責任感 }\end{array}$ \\
\hline
\end{tabular}




\begin{tabular}{|c|c|c|c|}
\hline 3 & 搜集二手資料 & $\begin{array}{l}\text { 1. 讓同學分頭進行二手資料的 } \\
\text { 檢索 } \\
\text { 2. 讓同學學習快速讀取有用資 } \\
\text { 訊的技巧 } \\
\text { 3. 鼓勵同學以心智圖作筆記 }\end{array}$ & $\begin{array}{l}\text { 讓同學掌握檢索資料的方 } \\
\text { 法並讀取有用資訊 }\end{array}$ \\
\hline 4 & 數碼眼新角度 & $\begin{array}{l}\text { 1. 讓同學透過作品欣賞認識數 } \\
\text { 碼攝影的技巧 } \\
\text { 2. 讓同學透過校園專題攝影實 } \\
\text { 習數碼攝影的技巧 } \\
\text { 3. 讓同學利用電腦科技剪輯作 } \\
\text { 品 }\end{array}$ & $\begin{array}{l}\text { 讓同學掌握數碼攝影的技 } \\
\text { 巧以輔助專題研習 }\end{array}$ \\
\hline 5 & |問 卷設計及訪 & $\begin{array}{l}\text { 1. 讓同學透過一個問卷調查初 } \\
\text { 步掌握問卷設計的要點 } \\
\text { 2. 讓同學就各組所擬定的假設 } \\
\text { 進行問卷設計以搜集一手資 } \\
\text { 料 } \\
\text { 3. 與同學設定進行問卷調查的 } \\
\text { 對象、時間和地點 } \\
\text { 4. 讓同學擬定訪問對像及問 }\end{array}$ & $\begin{array}{l}\text { 讓同學掌握問卷設計的技 } \\
\text { 巧及訪問, 強化與人溝通的 } \\
\text { 能力 }\end{array}$ \\
\hline
\end{tabular}




\begin{tabular}{|c|c|c|c|}
\hline & & $\begin{array}{l}\text { 題,並嘗試聯絡受訪者以搜集 } \\
\text { 一手資料 }\end{array}$ & \\
\hline 6 & 實地觀察 & $\begin{array}{l}\text { 1. 讓同學透過實地觀察掌握搜 } \\
\text { 集一手資料的技巧 } \\
\text { 2. 讓同學使用數碼攝影的技巧 } \\
\text { 搜集合適的一手資料 } \\
\text { 3. 讓同學進行問卷調查或訪問 }\end{array}$ & $\begin{array}{l}\text { 讓同學掌握搜集一手資料 } \\
\text { 的技巧 }\end{array}$ \\
\hline 7 & 資料整理 & $\begin{array}{l}\text { 1. 讓同學以心智圖及重點筆記 } \\
\text { 卡整理所得資料 } \\
\text { 2. 讓同學綜合所得資料驗証假 } \\
\text { 設，作初步結論 } \\
\text { 3. 與同學設定製作簡報的重點 }\end{array}$ & $\begin{array}{l}\text { 讓同學掌握處理資料的技 } \\
\text { 巧，提升學習能力 }\end{array}$ \\
\hline 8 & $\begin{array}{l}\text { 製作報告及準 } \\
\text { 備匯報 }\end{array}$ & $\begin{array}{l}\text { 1. 讓同學以簡報形式製作報告 } \\
\text { 2. 與同學設定口頭匯報的分工 }\end{array}$ & $\begin{array}{l}\text { 讓同學掌握製作報告的技 } \\
\text { 巧 }\end{array}$ \\
\hline 9 & $\begin{array}{l}\text { 展示報告、互評 } \\
\text { 及反思 }\end{array}$ & $\begin{array}{l}\text { 1. 讓同學分組作口頭簡報 } \\
\text { 2. 讓同學分組互評 } \\
\text { 3. 與同學透過檢視 } 「 \text { 專題研習學 }\end{array}$ & $\begin{array}{l}\text { 讓同學掌握口頭簡報的 } \\
\text { 技巧，強化表達能力 }\end{array}$ \\
\hline
\end{tabular}



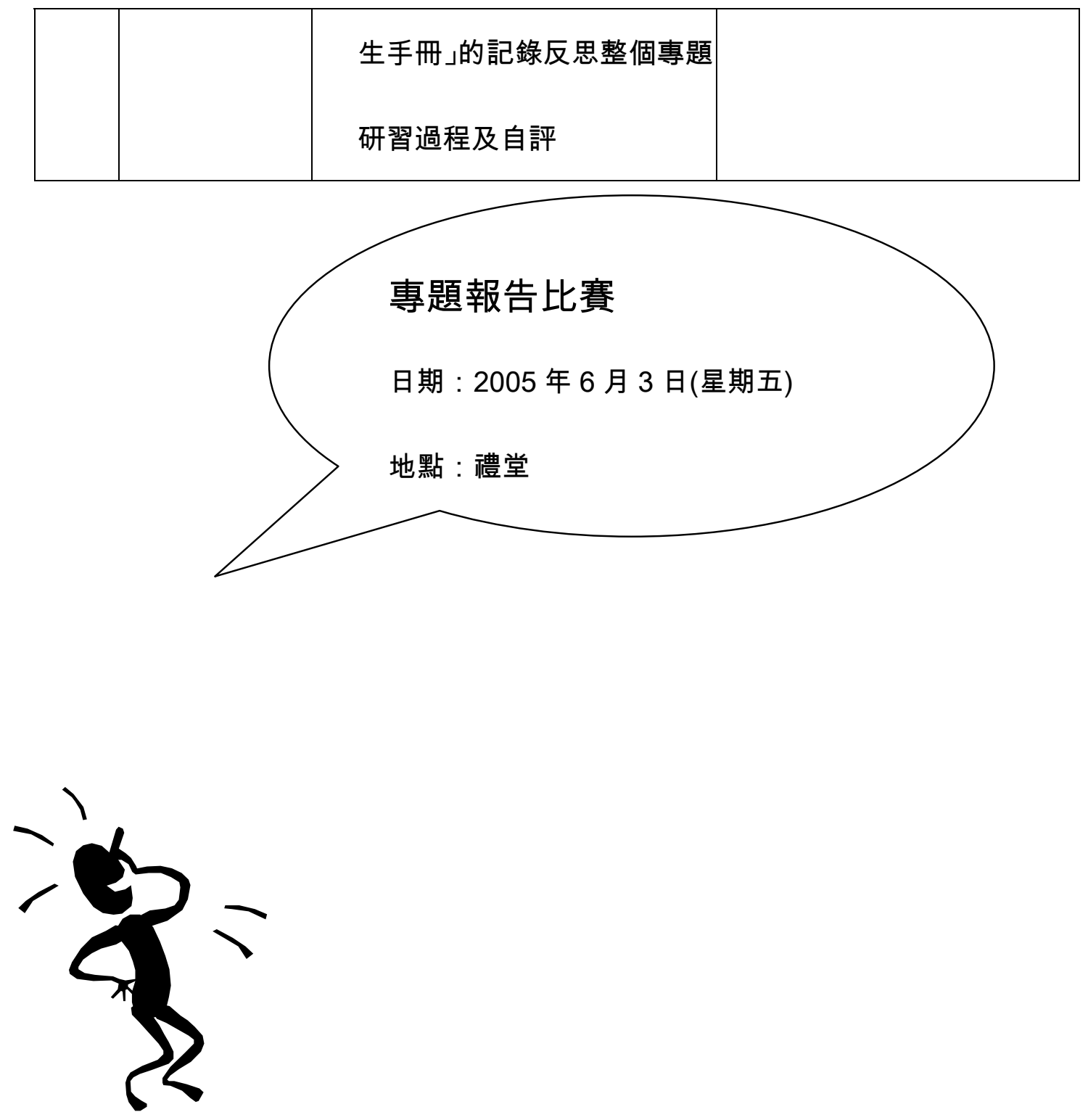
第一課堂：構思主題

優質專題報告的指標

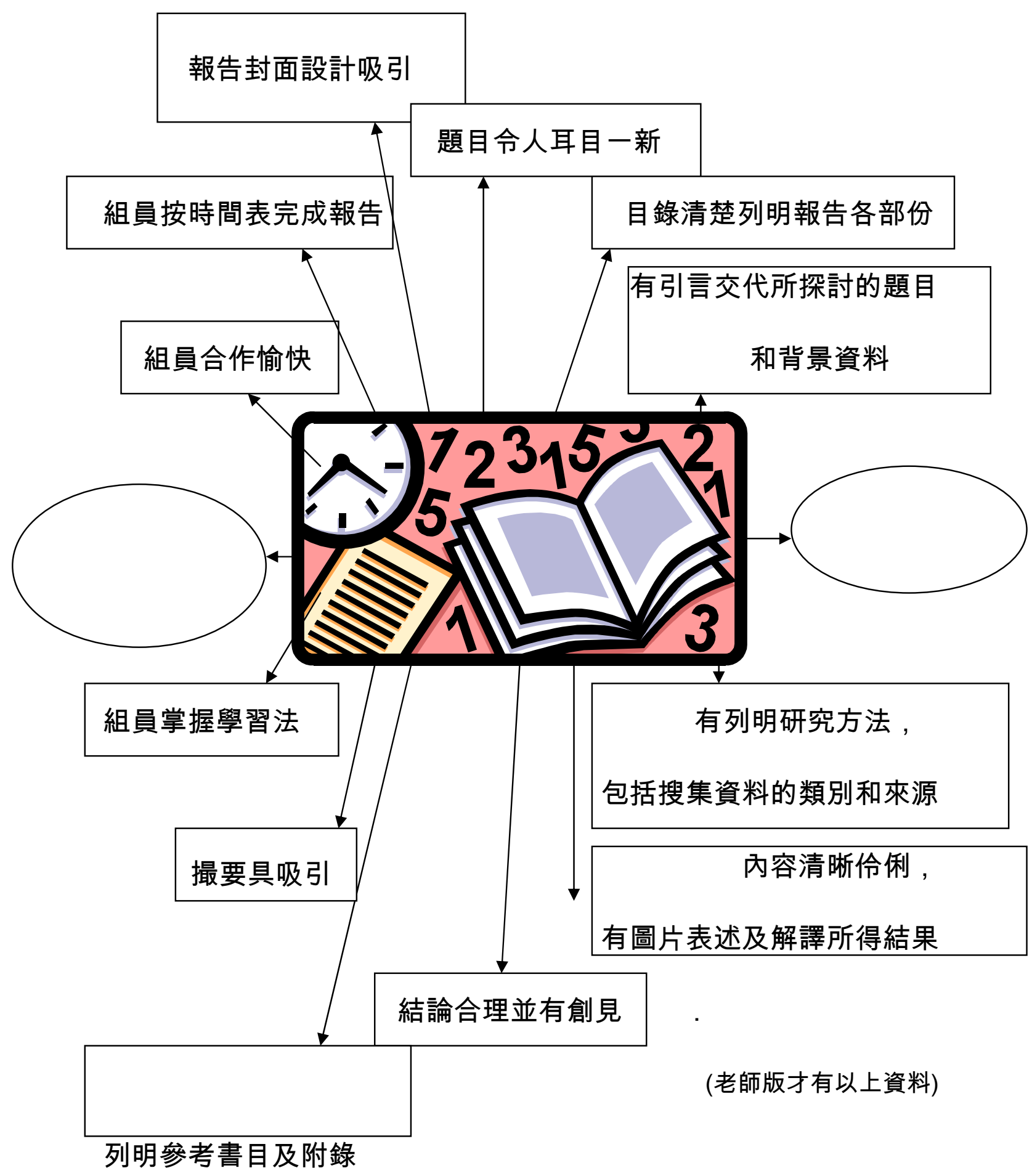




\section{問題敘述 $(-)$}

＜文匯報＞［香港新聞］（記者＼cjkstart聶曉輝）Ａ15 2004-03-17

\section{市建局首次強制收舖 (節錄)}

市區重建局引用《土地收回條例》, 首次派遣執達吏到深水埗強制收回兩 間商舖的業權，以配合重建計劃。有業主不肯遷出，遭強制抬走。市建局地 區發展總監麥振芳強調，他們已經用盡了所有辦法，唯兩間店舖合共索償逾 一億元, 實在很難接受, 而當局已提出約 120 萬及 95 萬的補償建議, 已經 $「$ 仁

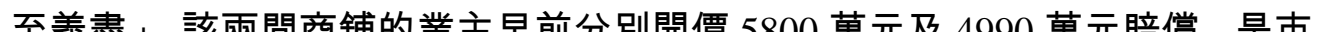
從剪報探究下列項目：

\begin{tabular}{|c|c|c|c|}
\hline 事實 & 意見/假設 & 學習目標 & 行動計劃 \\
\hline & & & \\
\hline & & & \\
\hline & & & \\
\hline & & & \\
\hline & & & \\
\hline & & & \\
\hline & & & \\
\hline & & & \\
\hline & & & \\
\hline
\end{tabular}


主題：

角色一：市區重建局代表

要求:

角色二：商鋪業主

要求:

角色三：區內居民

要求:

角色四： 深水埗區議會區議員

要求:

角色五：採訪記者

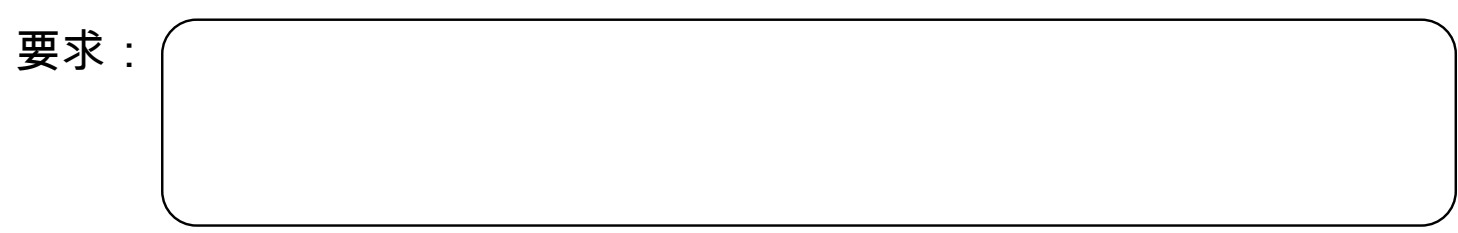

角色六：

要求: 
問題敘述 $($ 二)

<大公報 $>$ 李碧欣 2004-10-17 A08

\section{高低收入中位數差26倍深水埗全港最窮 香港貧富急劇惡化}

據今年聯合國報告顯示, 香港低收入家庭人數高達一百一十二萬

人, 而且是全球五大高發展地區中, 貧富懸殊最嚴重的地區之一。

全港最貧窮的三個地區分別是深水埗、觀塘及元朗，而深水埗亦是

全港最多貧窮兒童居住的地方。

從剪報探究下列項目：

\begin{tabular}{|l|l|l|l|}
\hline 事實 & 意見/假設 & 學習目標 & 行動計劃 \\
\hline & & & \\
\hline & & & \\
\hline & & & \\
\hline & & & \\
\hline
\end{tabular}


主題 :

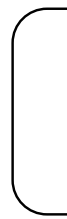

角色一：政府官員

要求:

角色二：社工

要求:

社工

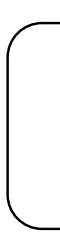


問題敘述(三)

<文匯報 $>$

2004-05-17

A24

\section{家鴉為患當局擬搗巢滅種 天性霸道欺凌本地雀鳥種群}

外來雀鳥品種一一家鴉, 入侵本地自然生態, 天性霸道, 嚴重排擠本地雀鳥種群, 甚至啄食其他本地雀鳥種群的雛鳥及鳥蛋; 另叫聲擾民及造成的種種衛生問題, 已令當 局難以再忍。消息人士透露, 政府有意毀滅家鴉繁殖的巢穴, 極力控制牠們急劇上升的 繁死數目, 避免香港成為「鴉患之都」! 家鴉數目由 1993 年有記錄以來約 15 至 30 隻， 大幅上升至去年的 269 隻, 近年更開始侵擾深水埗區一帶, 造成噪音、環境衛生等多項 從剪報探究下列項目：

\begin{tabular}{|l|l|l|l|}
\hline 事實 & 意見/假設 & 學習目標 & 行動計劃 \\
\hline & & & \\
\hline & & & \\
\hline & & & \\
\hline & & & \\
\hline
\end{tabular}


主題 :

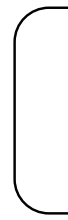

角色一：受影響居民

要求:

角色二：政府官員

要求:

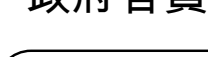

角色三： 保護野生動植物團體

要求:

角色四：

要求:

角色五:

要求:

角色六：

要求: 


\begin{tabular}{|c|l|l|l|l|l|l|}
\multicolumn{2}{c|}{ 組員第 } \\
\multicolumn{1}{|c|}{ 課堂表現評量表 } \\
\hline 項目 / 組員姓名 & & & & & & \\
\hline 積極參與討論 & & & & & & \\
\hline 敢於提出意見 & & & & & & \\
\hline 大膽假設 & & & & & & \\
\hline 創新思考 & & & & & & \\
\hline 尊重別人意見 & & & & & & \\
\hline 態度認真 & & & & & & \\
\hline 善用學生手冊 & & & & & & \\
\hline & & & & & & \\
\hline
\end{tabular}

老師對組員作以上評估, 每項目最高 5 分, 最低 1 分。

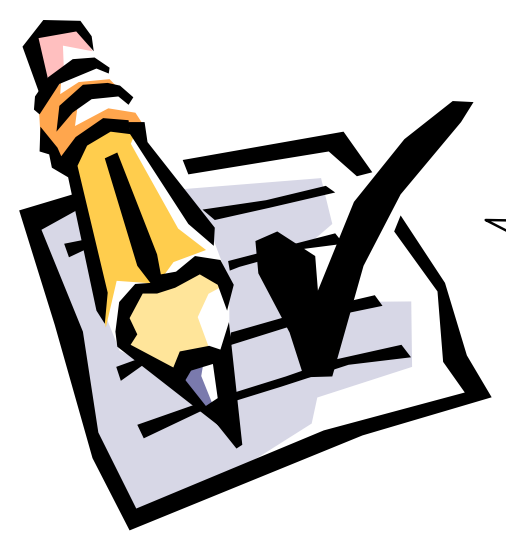

(老師版才有本頁)

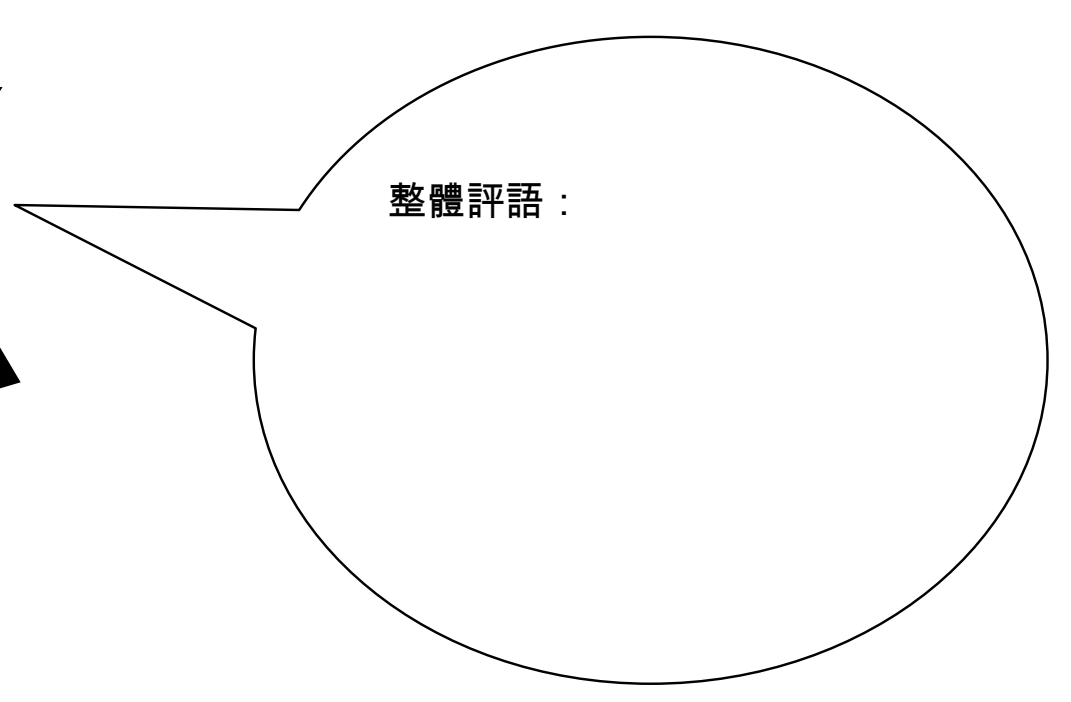




\section{組員第 課堂自評及互評表現評量表}

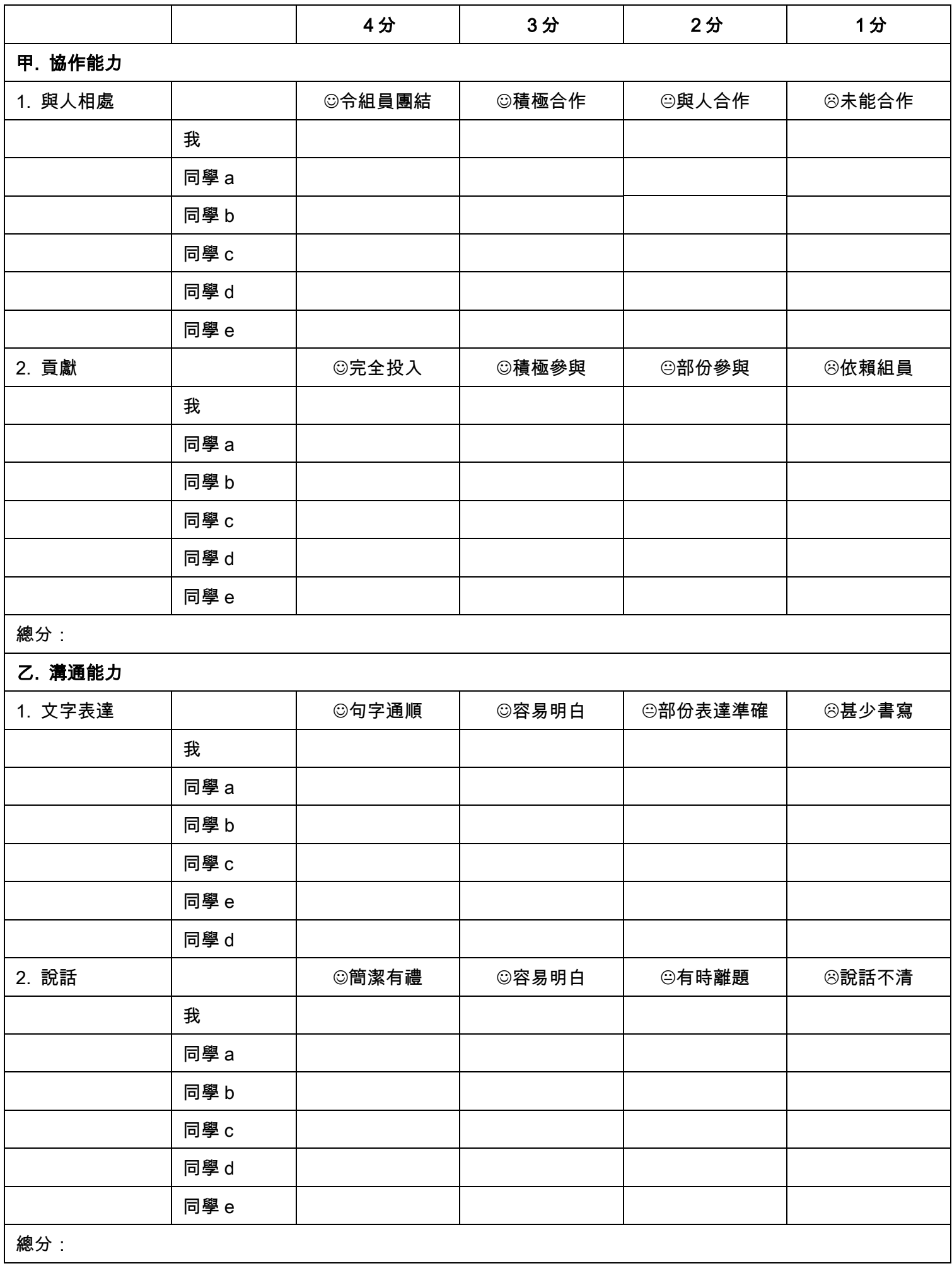




\begin{tabular}{|c|c|c|c|c|c|}
\hline \multicolumn{6}{|l|}{ 丙. 資料搜集 } \\
\hline \multirow[t]{7}{*}{ 1. 搜集資料方法 } & & ○完全掌握 & (i)熟悉 & $\odot$ 知道－點點 & ：完全不懂 \\
\hline & 我 & & & & \\
\hline & 同學 a & & & & \\
\hline & 同學 b & & & & \\
\hline & 同學 c & & & & \\
\hline & 同學 d & & & & \\
\hline & 同學 e & & & & \\
\hline \multirow[t]{7}{*}{ 2. 紀錄資料方法 } & & (-)完全掌握 & (-)熟悉 & $\odot$ 知道－點點 & ：完全不懂 \\
\hline & 我 & & & & \\
\hline & 同學 a & & & & \\
\hline & 同學 b & & & & \\
\hline & 同學 c & & & & \\
\hline & 同學 d & & & & \\
\hline & 同學 e & & & & \\
\hline 總分 & & & & & \\
\hline
\end{tabular}

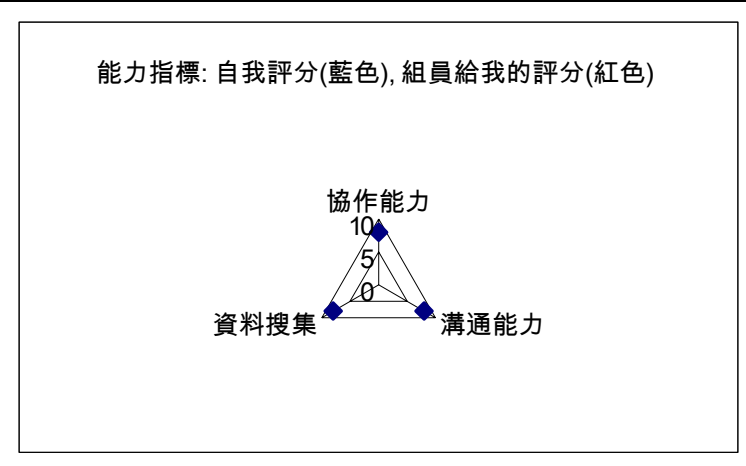

小問卷

\begin{tabular}{|l|l|l|l|l|l|l|}
\hline & & 非常同意 & 同意 & \multicolumn{1}{|c|}{ 普通 } & 不同意 & 極不同意 \\
\hline 1 & 老師讓我們自行控制學習過程 & & & & & \\
\hline 2 & 老師會指導我們集中注意力在議題上 & & & & & \\
\hline 3 & 老師有效地鼓勵我們各人積極參與 & & & & & \\
\hline 4 & 老師在適當的時候提供問題的背景資料 & & & & & \\
\hline 5 & 老師只在必要的時候提供指引 & & & & & \\
\hline 6 & 老師理解我們的意見 & & & & & \\
\hline 7 & 老師引導我們對問題作批判式思考 & & & & & \\
\hline
\end{tabular}

\section{第二課堂：修定題目}




\section{$「$ 心智圖思考法」}

秘訣：不作任何篩選地將腦中浮現的意念或題目以重點方式記錄, 然後到圖 書館翻翻資料，再修定題目。

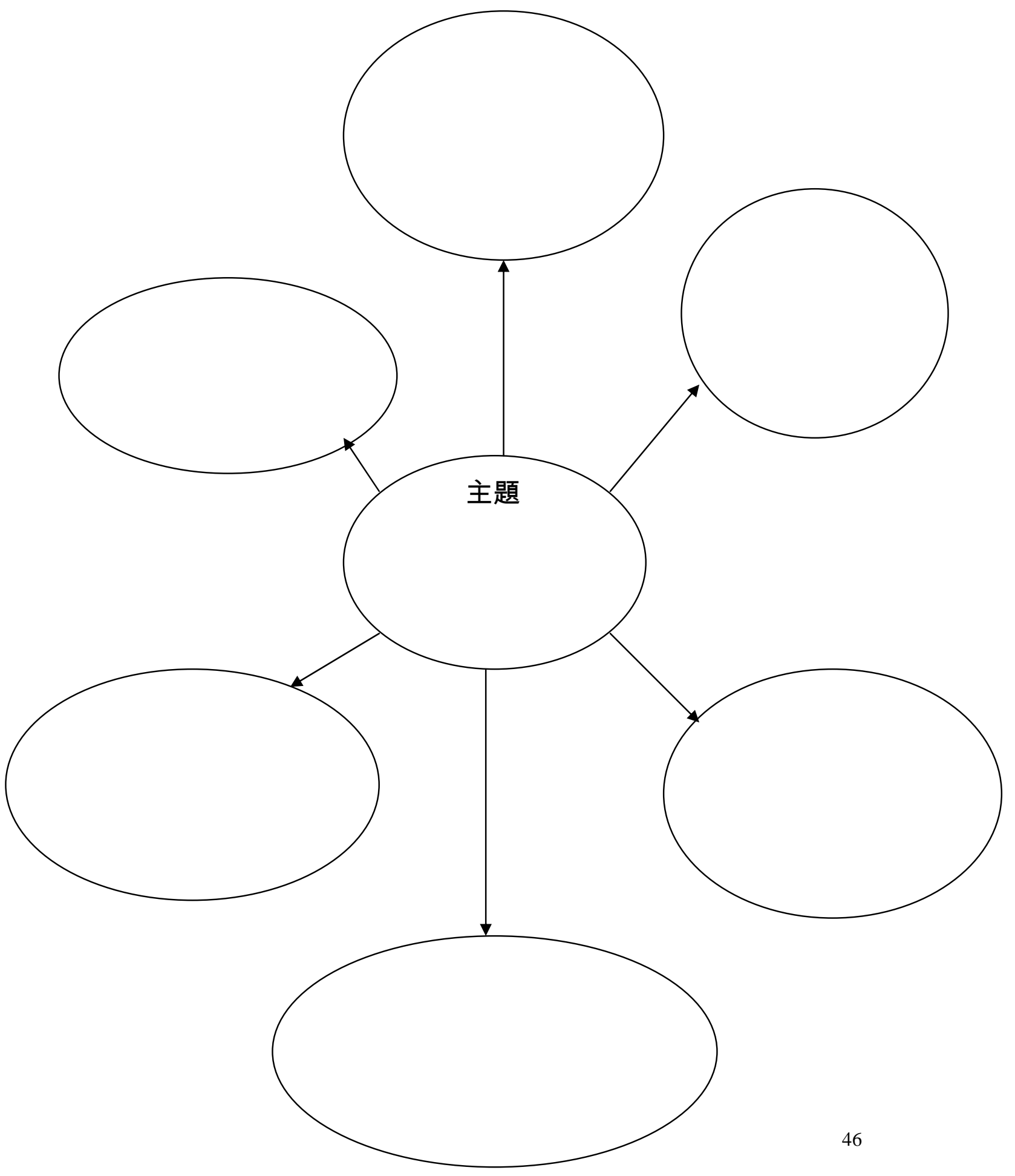




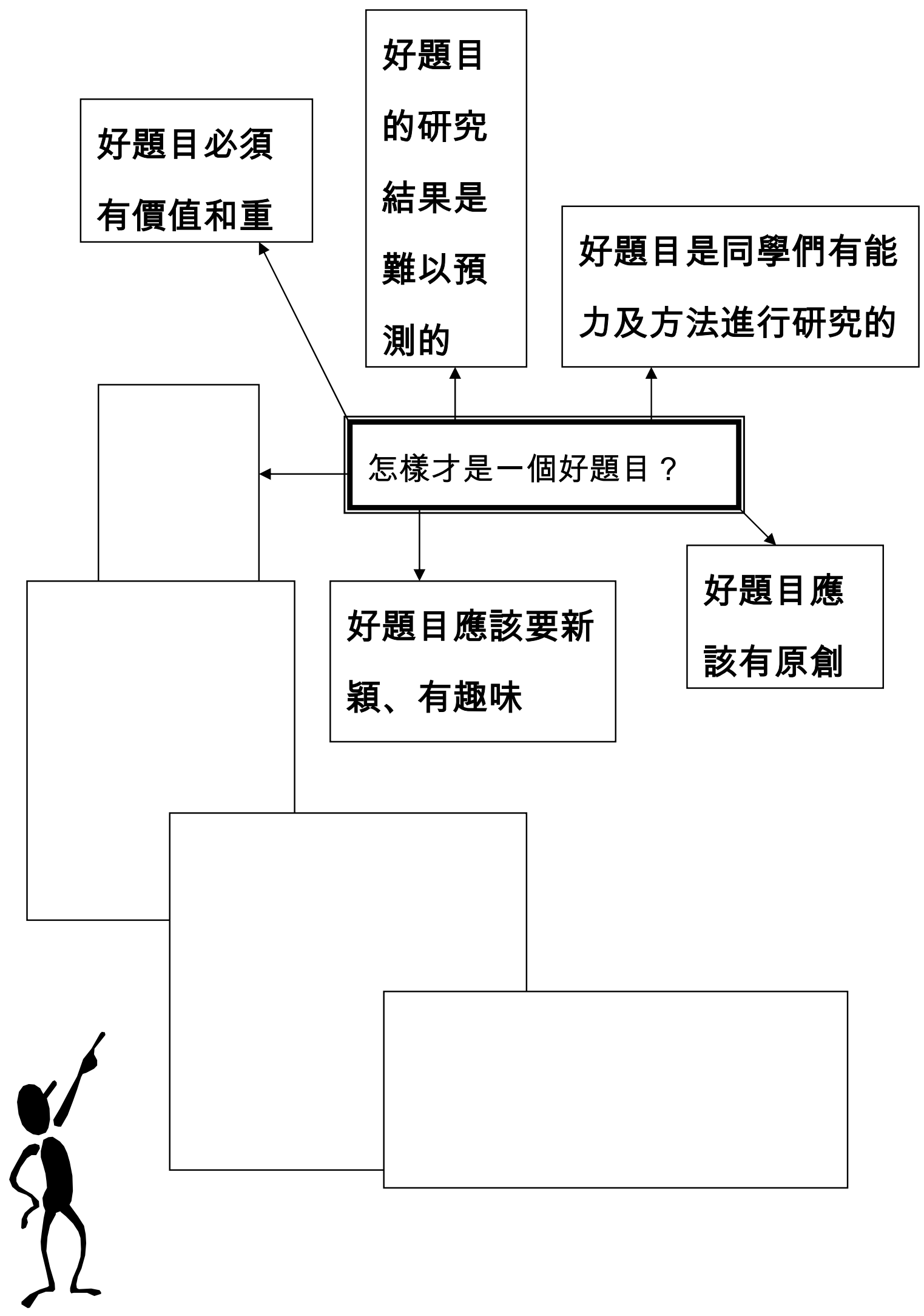


擬定 KND 表

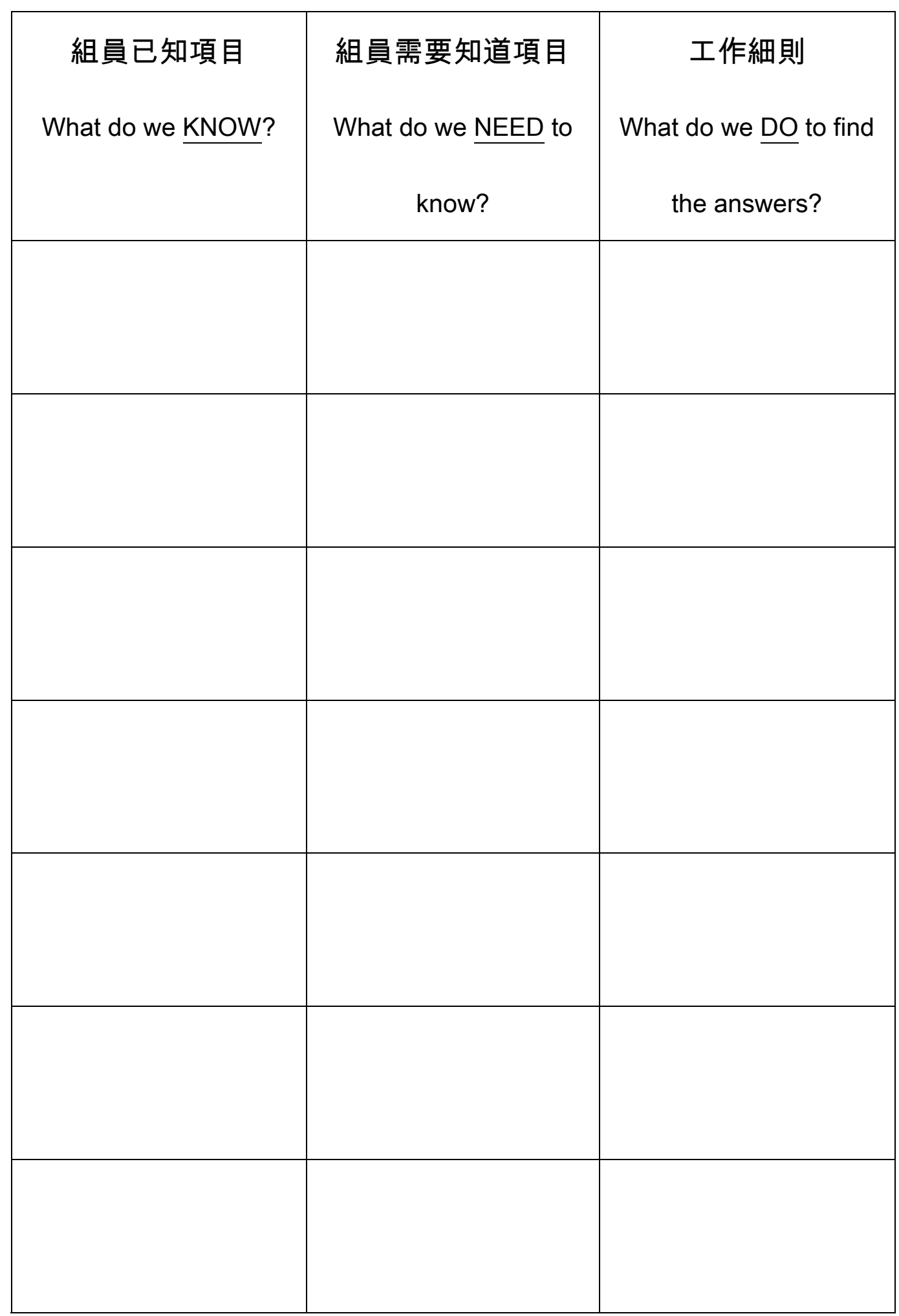




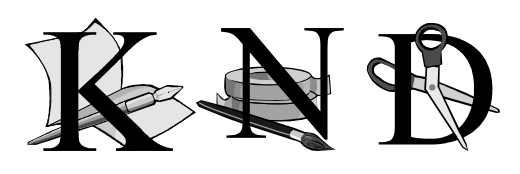

檢索資料途徑及類別

\begin{tabular}{|c|c|c|c|c|c|c|}
\hline 資料 & 一手 & 二手 & 印刷 & 非印刷 & 官方 & 非官方 \\
\hline 百科全書 & & is & ts & & & \\
\hline 書籍 & & is & is & & & \\
\hline 雜誌 & & is & is & & & \\
\hline 報章 & & is & is & & & \\
\hline 年報 & & is & is & & is & \\
\hline 互聯網頁 & & is & & is & & \\
\hline 電腦光碟 & & is & & is & & \\
\hline 影音光碟 & & is & & is & & \\
\hline 地圖 & & is & & & & \\
\hline 訪問 & is & & & is & & \\
\hline 問卷調查 & is & & is & & & \\
\hline 實驗 & is & & & is & & \\
\hline 實地考察 & is & & & is & & \\
\hline 日記 & is & & is & & & \\
\hline
\end{tabular}


一手資料：由那些親身經歷事件的人所記錄的資料稱為第一手資料。

二手資料：由那些未親身經歷事件的人所記錄的資料，即一些轉述的記載。

考慮取用資料原則：可信度、重要性、時間性、事實 vs 意見

(老師版才有以上資料) 
第三課堂：搜集二手資料

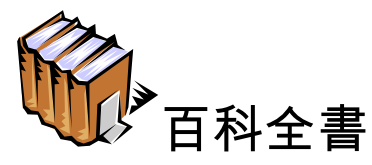

書目資料：題目 (出版年份). <<書名〉> (冊數, 頁數). 出版地 : 出版 社.

\begin{tabular}{|l|l|l|}
\hline 填寫日期 & 筆記重點 & 頁數 \\
\hline & & \\
\hline & & \\
\hline & & \\
\hline & & \\
\hline
\end{tabular}

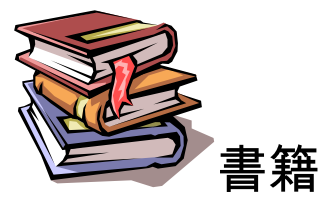

書目資料: 作者 / 機構 (出版年份). 《<書名〉>. 出版地 : 出版社.

\begin{tabular}{|l|l|l|}
\hline 填寫日期 & 筆記重點 & 頁數 \\
\hline & & \\
\hline & & \\
\hline & & \\
\hline
\end{tabular}




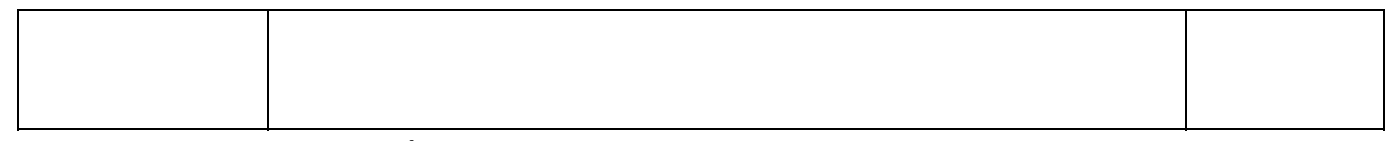
新詰

書目資料：題目 (出版日期). 《<書名 > (期號, 頁數).

\begin{tabular}{|l|l|l|}
\hline 填寫日期 & 筆記重點 & 頁數 \\
\hline & & \\
\hline & & \\
\hline & & \\
\hline & & \\
\hline
\end{tabular}

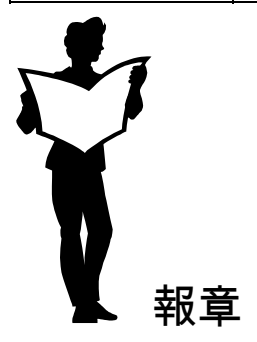

書目資料：作者 / 機構 (出版日期). 題目. 《<報章名稱 $>$, 版頁.

\begin{tabular}{|l|l|l|}
\hline 填寫日期 & 筆記重點 & 頁數 \\
\hline & & \\
\hline & & \\
\hline & & \\
\hline
\end{tabular}




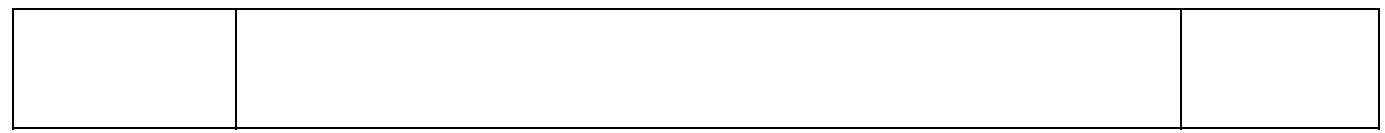




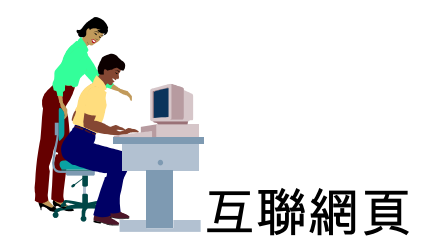

\begin{tabular}{|c|c|c|}
\hline 填寫日期 & 筆記重點 & 備註 \\
\hline & & \\
\hline & & \\
\hline & & \\
\hline & & \\
\hline
\end{tabular}

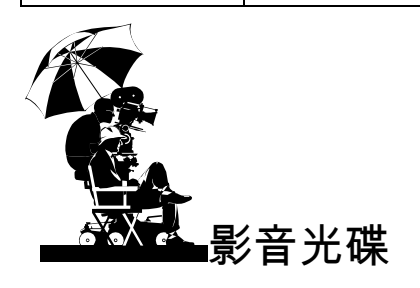

書目資料：製作機構 (出版年份). 《影片名稱〉> [影音光碟]. 出版 地：出版社.

\begin{tabular}{|l|l|l|}
\hline 填寫日期 & 筆記重點 & 備註 \\
\hline & & \\
\hline & & \\
\hline
\end{tabular}




\begin{tabular}{|l|l|l|}
\hline & & \\
\hline & & \\
\hline
\end{tabular}

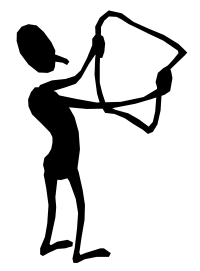

快速讀取有用資訊的技巧：瘦身覽文法

大原則：刪除廢話，畫記重點！

方法：

1. 細閱標題 $\rightarrow$ 明白標題能使你閱讀整篇文章時事半功倍

2. 略讀簡介 $\rightarrow$ 概述整篇文章

3. 閱讀段首 $\rightarrow$ 一個段落的首句或次句，很多時候正是整段的主題

4. 留意專有名詞 $\rightarrow$ 地名、人名等都是重要資料

5. 留意數字 $\rightarrow$ 多是重要資料

6. 留意特別字體 $\rightarrow$ 粗體、全部大寫、斜體等都是特別資料

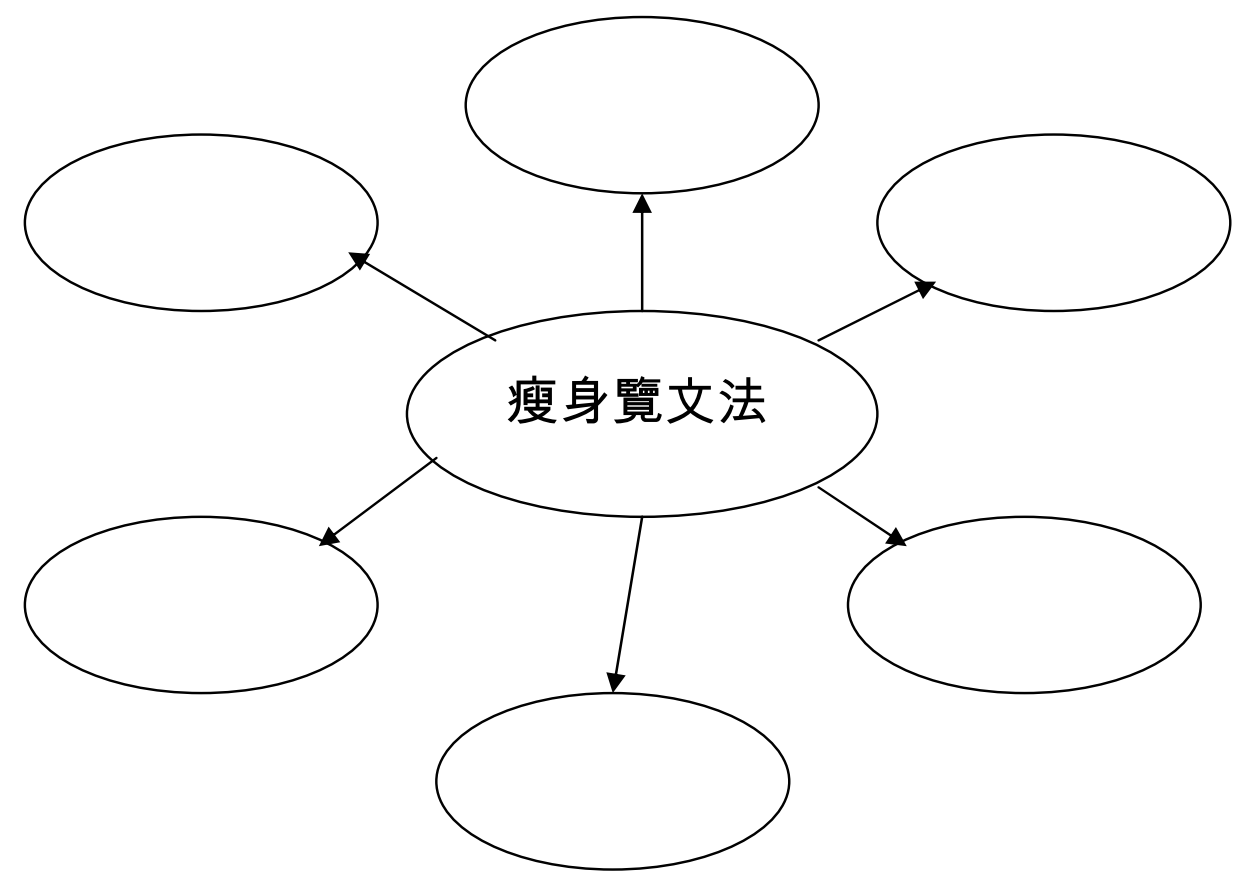


以心智圖幫助記憶「瘦身覽文法」的六點。 


\section{第四課堂：數碼眼新角度}

\section{認識數碼相機}

數碼攝影是拍照上的最新科技。數碼相機的運作方式與一般相機大同小異，最大 的差別是數碼相機不用底片，光線捕捉系統是一片位於鏡頭後方的電子晶片。晶 片捕捉光線，形成由小點(即像素)構成的影像。影像會立刻出現在相機背面的螢 幕上，照片拍好馬上就能看，修正錯誤可立即補拍，但電池也耗得兇。

數碼記憶卡與底片不同, 可以清除後再使用。既然不必擔心購買底片及沖霞相片 的費用，讓我們多作試驗，放手去拍吧！

\section{基礎攝影}

- 選定主題

- 找出光線的來源

- 消除雜亂的構圖

- 控制明暗對比

- 選出最佳角度

- 未必要將主題置於照片中央

- 使用閃光燈時要防止反射及減低紅眼現象

- 當拍攝全身人物相時不要裁掉雙腳 


\section{借用數碼相機及護理}

- 本校圖書館有數碼相機供同學借用, 請帶備學生証辦理手續

- 所借數碼相機附環保電池及 $128 \mathrm{MB}$ 記憶卡, 用後需同機交還

- 請小心使用數碼相機, 切勿跌撞機身

- 請勿用手碰觸鏡頭, 也不要用任何物品清潔鏡頭

- 避免在強力電流或磁埸的環境使用數碼相機

- 避免溫度的劇變

- 將數碼相機貯藏在清潔及乾燥的地方

- 同學不小心使用數碼相機引至損壞，需按情況賠償！
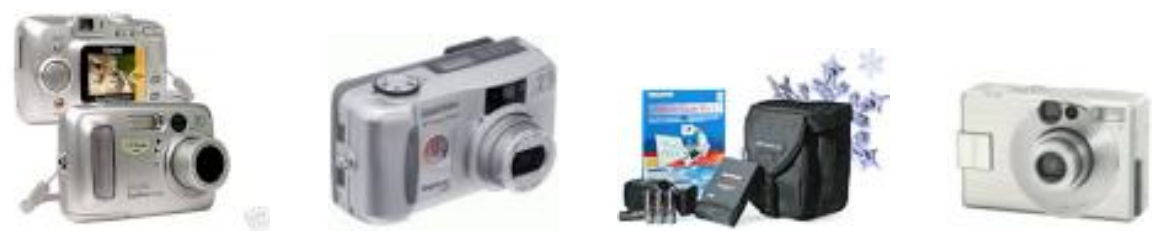


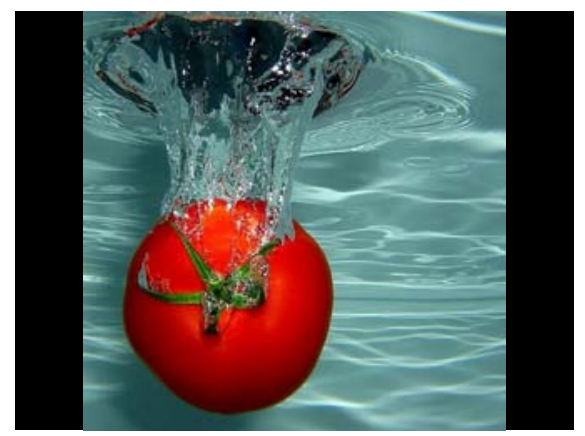

如何拍張好照片?
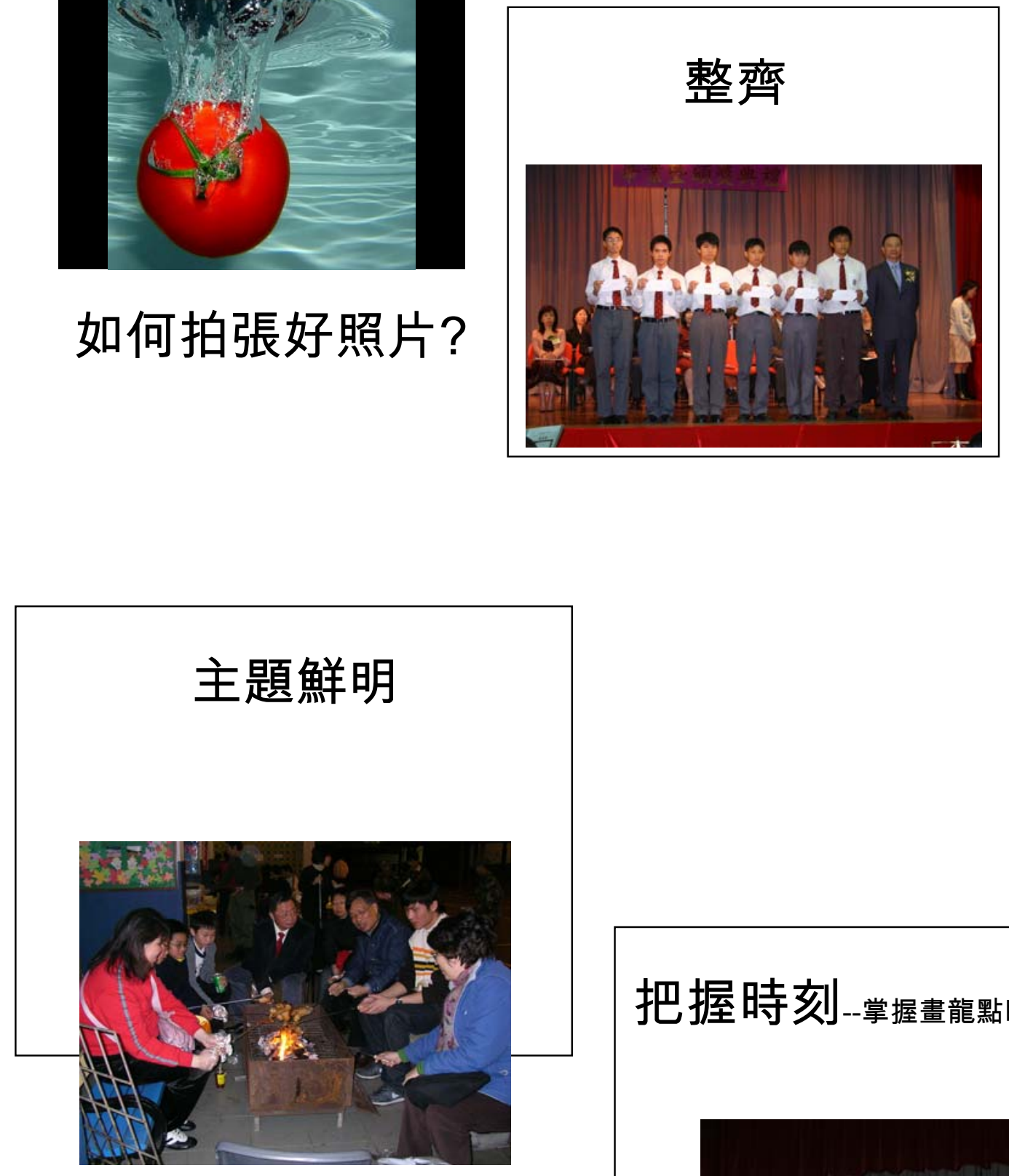

把握時刻--掌握畫龍點睛之妙!

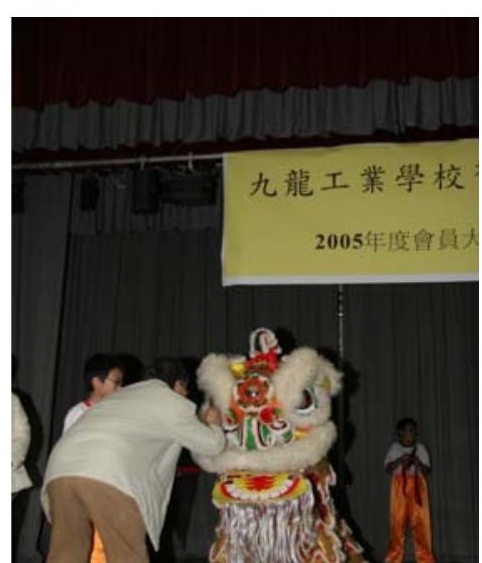




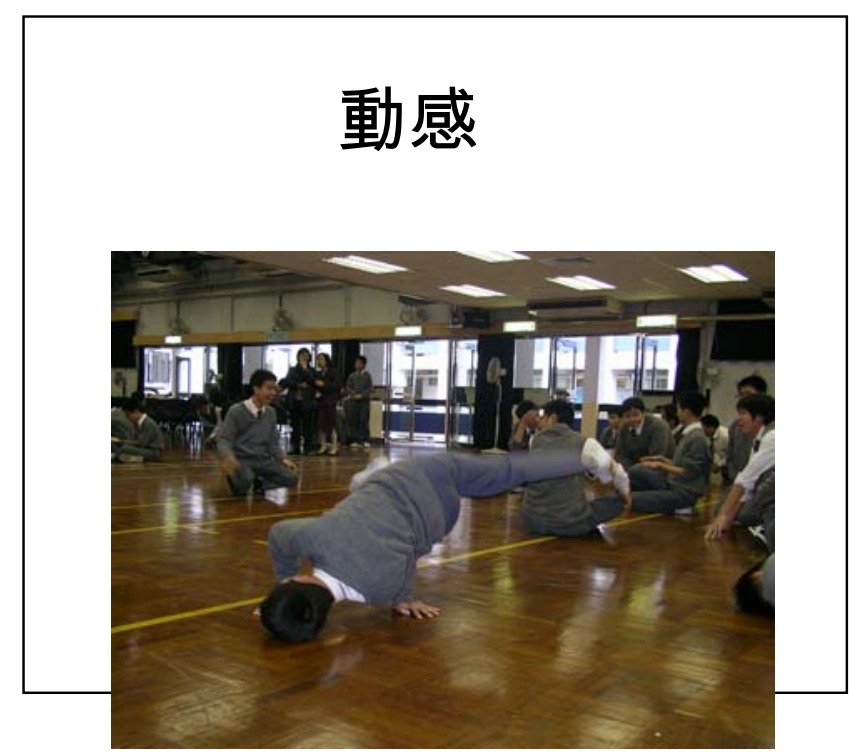

準備 Wide Angle 鏡頭 

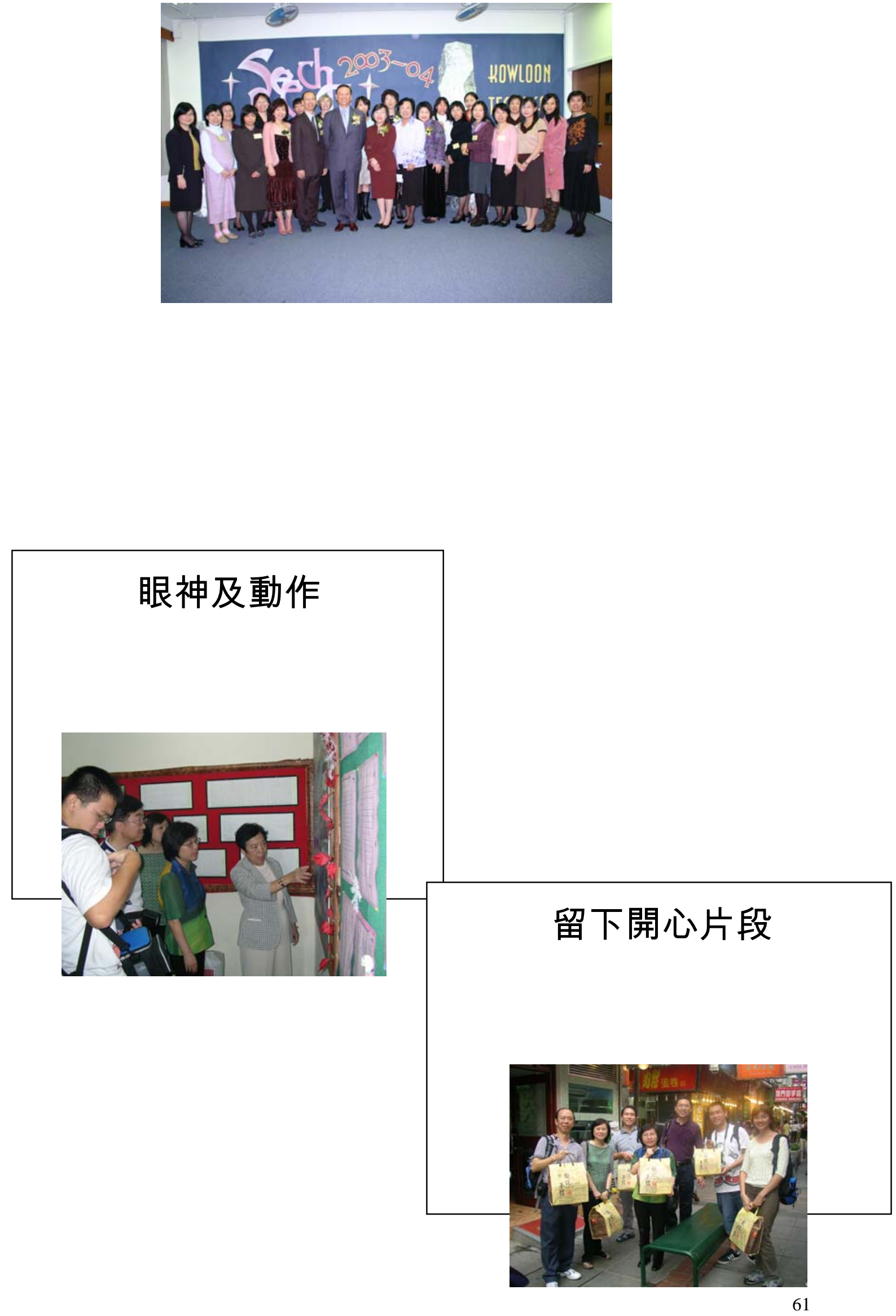


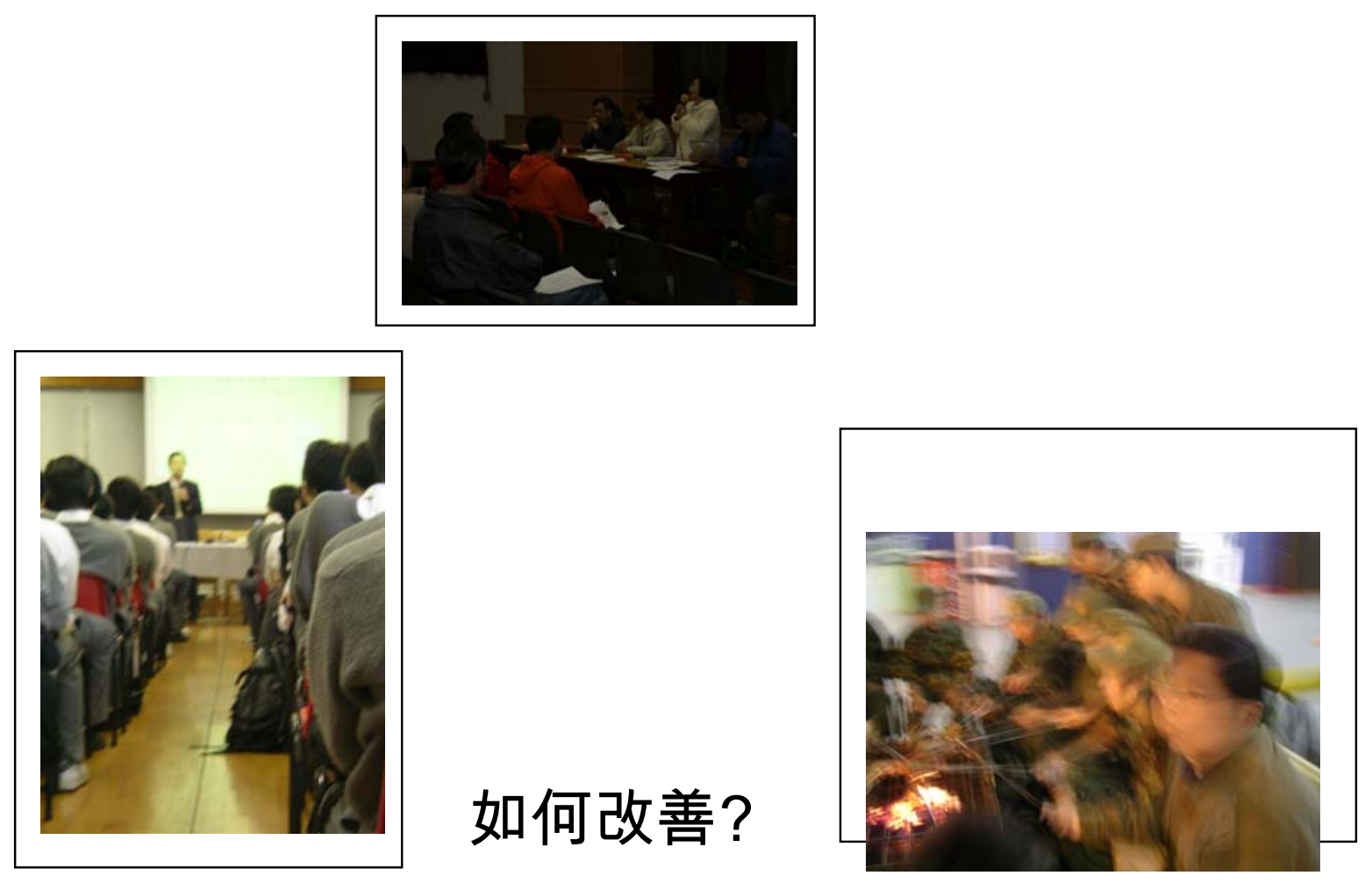


第五課堂：問卷設計及訪問

先確定以下細節 :

\begin{tabular}{|c|c|c|}
\hline \multicolumn{3}{|l|}{ 調查題目 } \\
\hline $\begin{array}{c}\text { 調查目的 } \\
\text { (想得的數據) }\end{array}$ & & \\
\hline \multicolumn{3}{|l|}{ 調查對象 } \\
\hline \multicolumn{3}{|l|}{ 樣本人數 } \\
\hline 抽樣方法 & \multicolumn{2}{|c|}{ 簡單隨機抽樣 / 著意性抽樣 ... } \\
\hline 收集問卷方式 & \multicolumn{2}{|c|}{ 當面訪問 / 自填問卷 / 郵寄問卷 / 電話訪問 } \\
\hline \multicolumn{3}{|l|}{ 進行調查時間 } \\
\hline \multicolumn{3}{|l|}{ 進行調查地點 } \\
\hline \multicolumn{3}{|c|}{ 指示要清楚易明 避免包括與研究沒有關係的問題 } \\
\hline \multicolumn{2}{|c|}{ 供選擇的答案項目要包括「其他」 } & 避免直接詢問受訪者確切的年齡收入 \\
\hline \multicolumn{2}{|c|}{ 同一個題目的選項須互相排斥 } & 不要用具「引導性」的問題 \\
\hline \multicolumn{2}{|l|}{ 問題要具體 } & 不要用具「傾向性」的問題 \\
\hline \multicolumn{2}{|c|}{ 預留空間給受訪者填寫意見 / 資料 } & 不要一題多問 \\
\hline
\end{tabular}


問卷例子
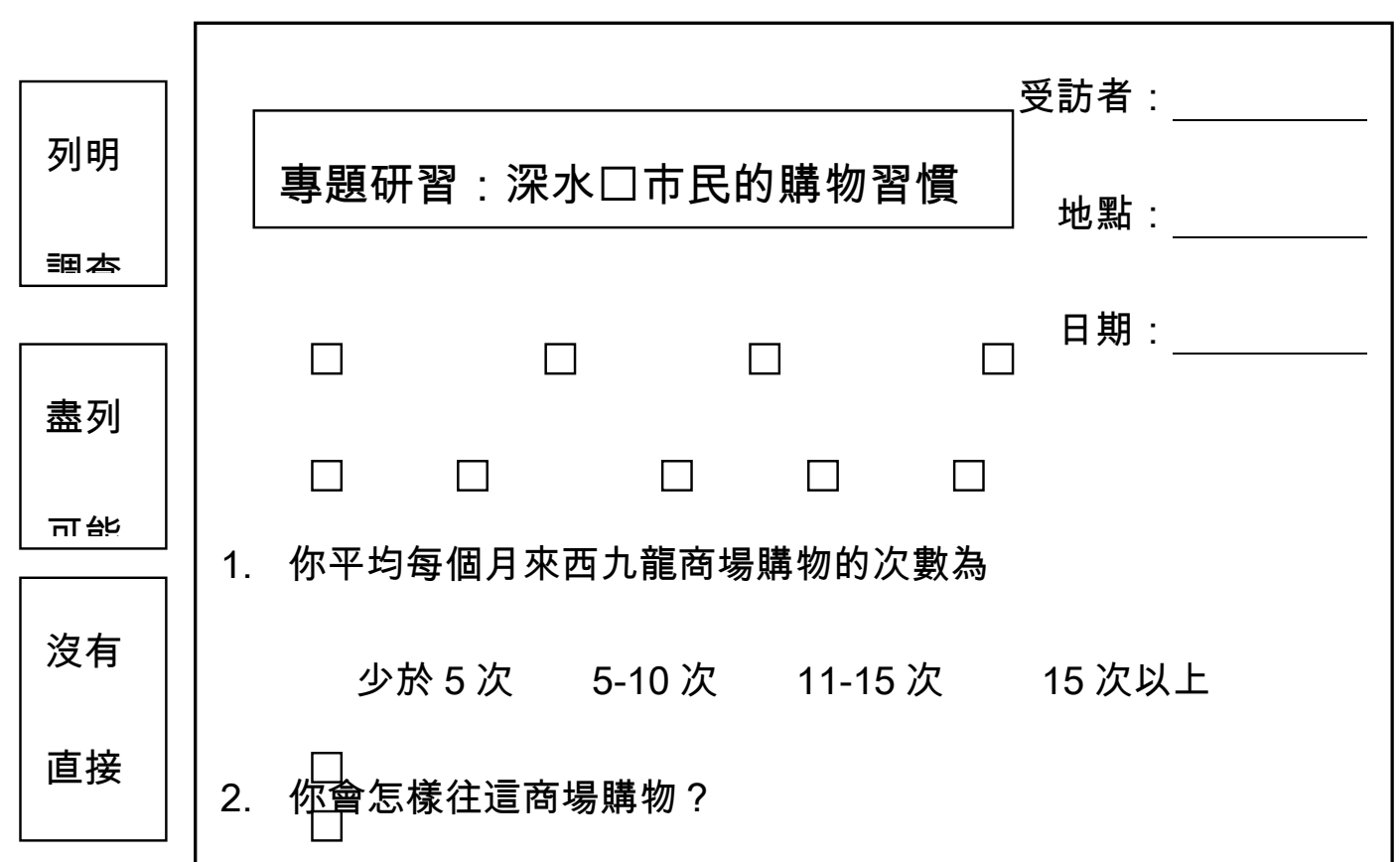

少於 5 次 5-10 次 11-15 次 15 次以上

2. 你會怎樣往這商場購物?
$\square$ 行路
私家車
巴士 地鐵 其他

3. 你住在哪一區 ?

\begin{tabular}{|l|}
\hline 預留 \\
空間 \\
給受
\end{tabular}

4. 為甚麼選擇在這裡購物呢?

在附近的地方居住

\begin{tabular}{|l|}
\hline 詢問個 \\
人資料 \\
的闍影 \\
\hline 向受訪 \\
圭示 \\
\hline
\end{tabular}

$\square$ 在附近的地方工作

多些商品的選擇

環境舒適

其他

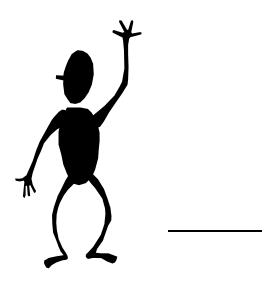

5. 你通常會在這裡購買哪類物品 ?

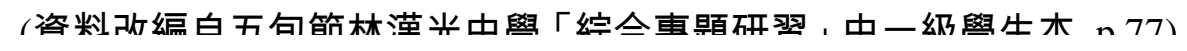


專題研習題目：

受訪者 :

地點：

訪問員：

日期：

1.

$\square$

$\square$

$\square$
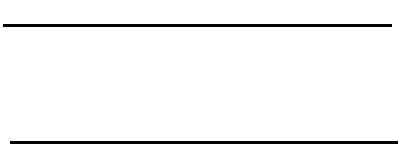

\section{其他}

2.

$\square$

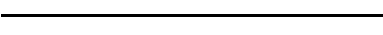

$\square$

$\square$
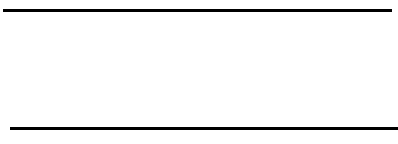

其他

3.

$\square$

$\square$

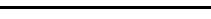

$\square$

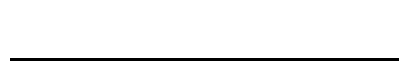

其他

4.

5. 
問卷完畢，多謝合作放 
訪問技巧

1. 選定受訪者

2. 避免在受訪者忙碌的時候進行訪問

3. 先向受訪者介紹自己, 並說明訪問的目的和所需時間

4. 帶備學生証以便受訪者稽查

5. 先徵得受訪者同意才進行錄影或錄音

6. 盡量避免中止受訪者的談話

7. 即使不贊成受訪者的談話內容, 不要顯得不耐煩

8. 避免在訪談中加入自己的觀點

9. 必須保持應有的禮貌和儀表, 即使對方拒絕受訪, 亦須道

謝

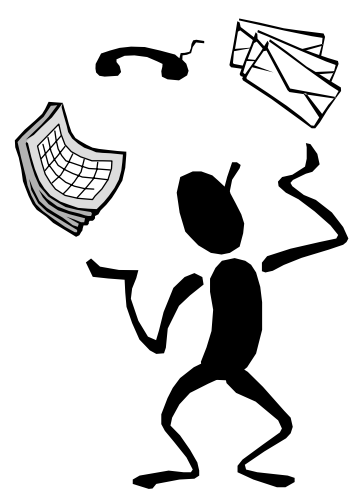




\section{數據處理}

\section{1. 用統計圖表來表述分析結果}

使用 Excel 軟件可畫出多種統計圖

a. 統計表

同學上學選用交通工具調查表

例子：

b. 統計圖

\begin{tabular}{|c|c|c|}
\hline 交通工具類別 & 數量 & $\%$ \\
\hline 私家車 & 28 & 5.6 \\
\hline 巴士 & 172 & 34.4 \\
\hline 小巴 & 56 & 11.2 \\
\hline 的士 & 5 & 1 \\
\hline 地鐵 & 158 & 31.6 \\
\hline 西鐵 & 63 & 12.6 \\
\hline 其他 & 18 & 3.6 \\
\hline 合計 & 500 & 100 \\
\hline
\end{tabular}




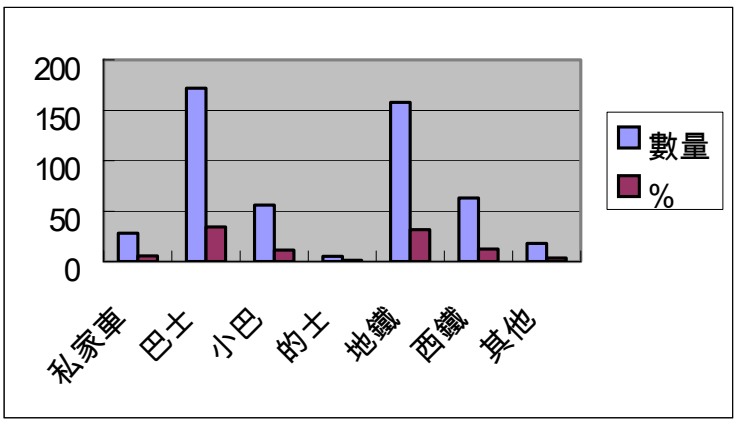

\section{C. 圓瓣圖}

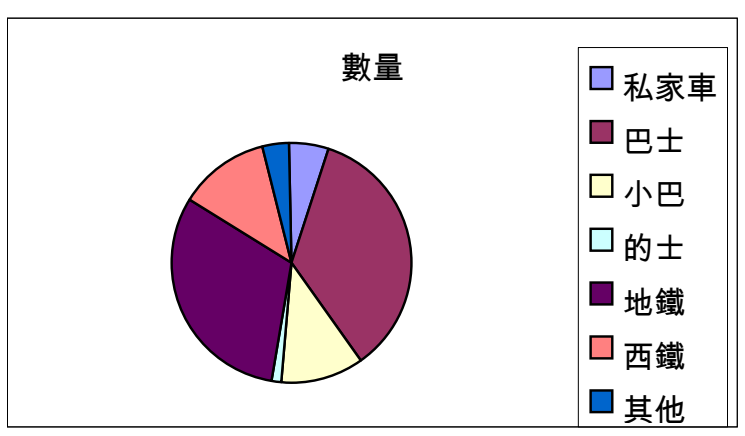




\section{第六課堂 : 實地觀察}

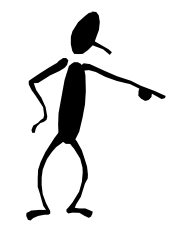

先確定以下細節：

\begin{tabular}{|c|c|}
\hline 觀察題目 & \\
\hline 觀察目的 & \\
(想得的數據) & \\
\hline 觀察對象 & \\
\hline 觀察地點 & \\
\hline 進行觀察路線 & \\
(地圖) & \\
\hline 行程安排 & \\
\hline (申請手續) & \\
\hline 進行觀察時間 & \\
(集合及解散) & \\
\hline 所需用品 & \\
\hline
\end{tabular}


實地觀察重點

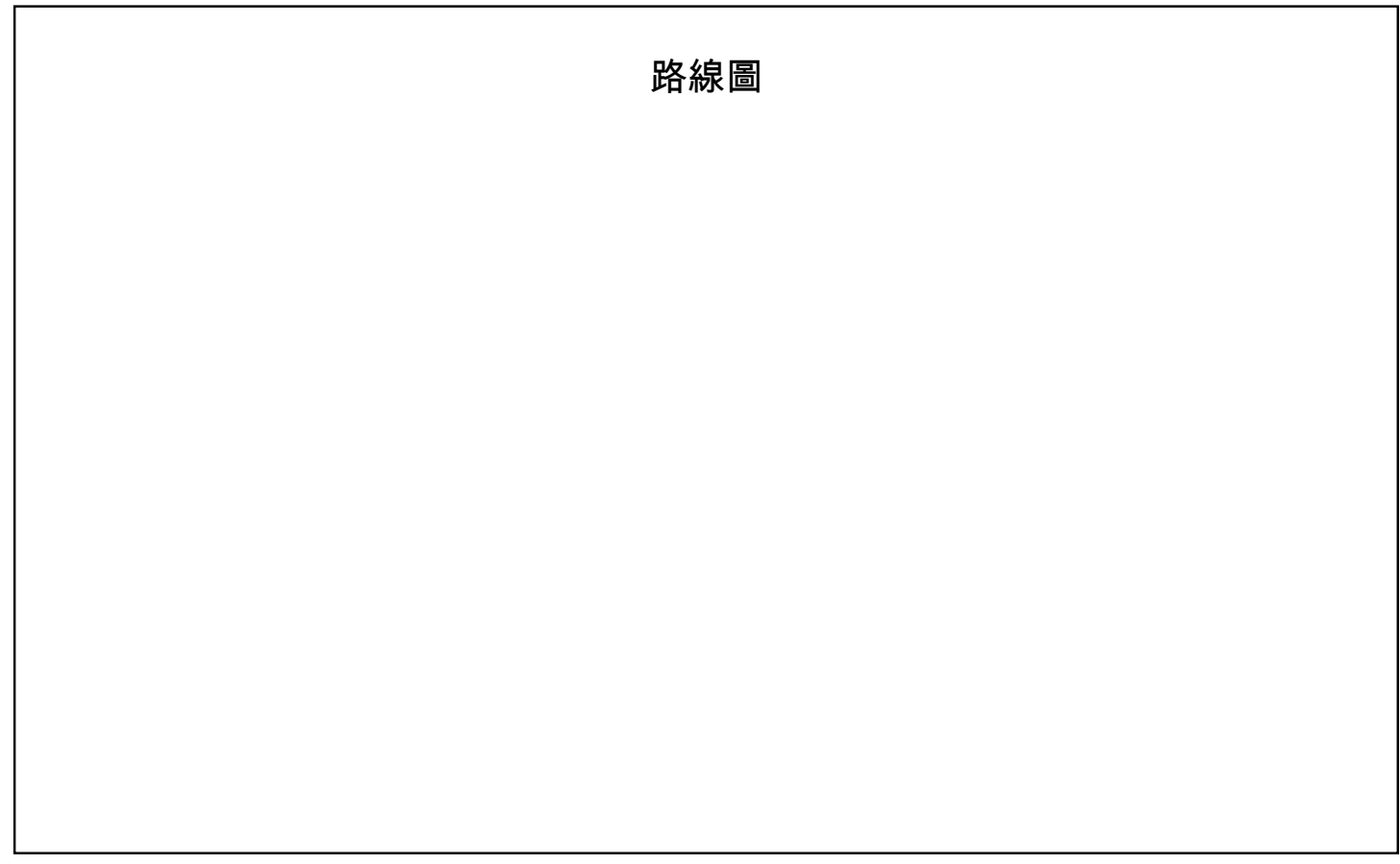

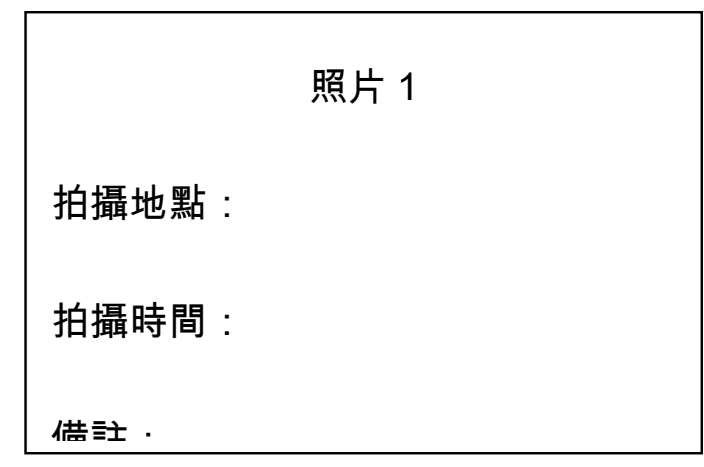

照片 2

拍攝地點：

拍攝時間：

借售。

照片 4

照片 3

拍攝地點 :

拍攝地點：

拍攝時間：

拍攝時間：

備註 :

備註：

\section{重點：}




\section{第七課堂：資料整理}

\section{1. 先將資料依 KND 表分類}

2. 用心智圖表達資料之間的關係

3. 綜合資料來解答擬探討的問題

4. 用 PowerPoint 軟件製作報告

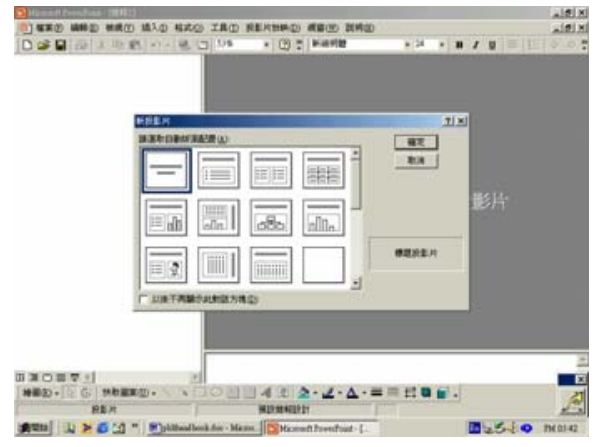

報告包括項目：

1. 封面 $\rightarrow$ 題目 / 學科 / 組別 / 組

員 / 完成日期

2. 目錄

3. 引言 $\rightarrow$ 研究主題 / 目的 / 範圍 / 背景資料

4. 研究方法 $\rightarrow$ 研究設計 / 選取樣本方法 / 搜集數據時間、地點、 方法

5. 內容 $\rightarrow$ 資料經過分析和整理後的結果 / 用地圖、相片、統計圖 表來解釋所得結果

6. 結論 $\rightarrow$ 概述重要的結果 / 結果是否支持當初的假設 / 對研習 題目提出建議

7. 參考書目

8. 附錄 $\rightarrow$ 問卷 / 訪問問題 / 不同角色要求部份

9. 鳴謝 (有關人士) 
第八課堂：製作報告及準備匯報

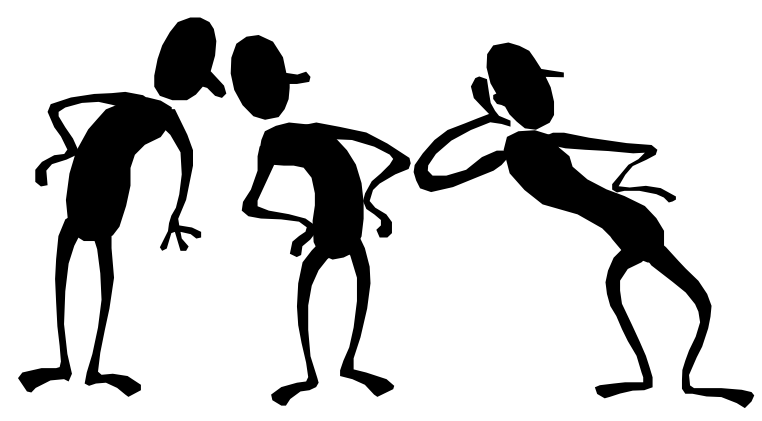

分工？合作？演講？角色扮演？

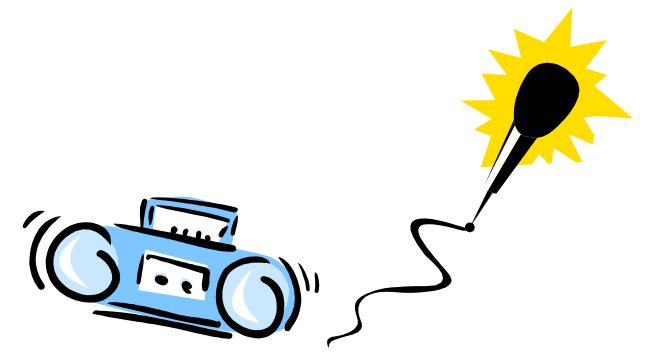

用錄音帶將口頭匯報錄下來，以觀眾角度來找出可改進之處。
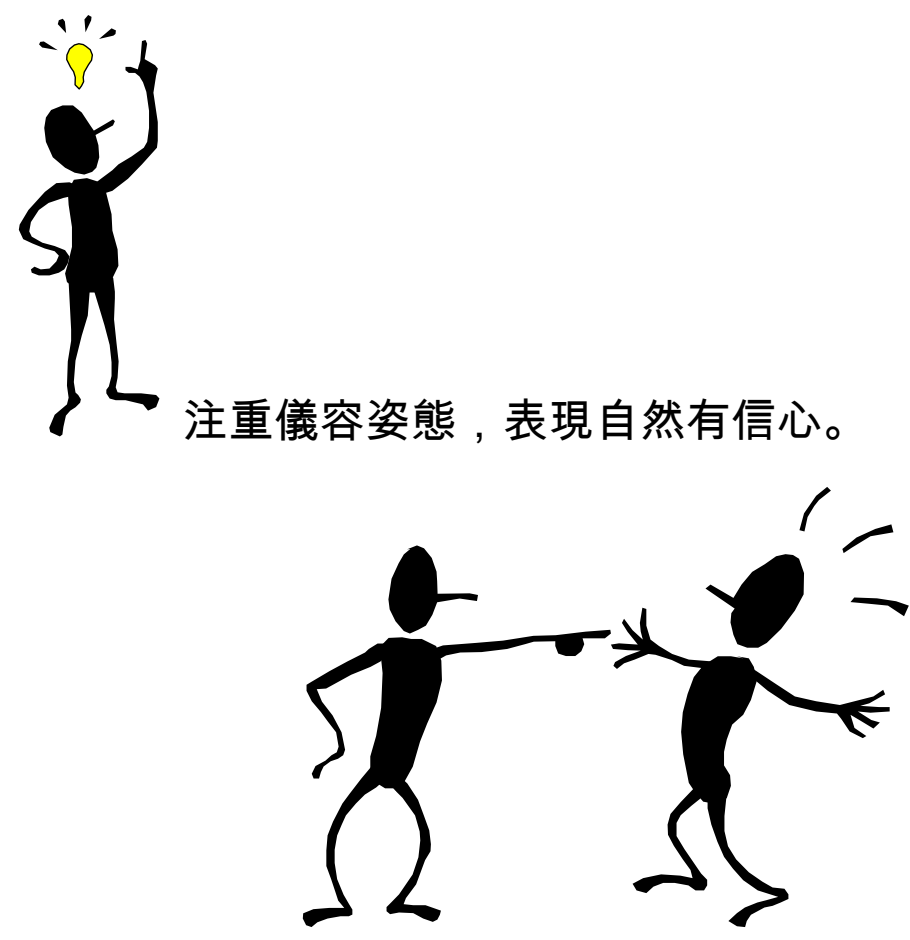

提高聲量, 咬字清晰, 配合適當的身體語言, 以及善用目光接觸觀眾。 
第九課堂 : 展示報告、互評及反思

專題研習互評表組名：

\begin{tabular}{|c|c|c|c|c|}
\hline 組別 & 專題題目 & 評審準則 & $\begin{array}{c}\text { 分數 } \\
\text { (最高 } 5 \text { 分) }\end{array}$ & $\begin{array}{l}\text { 備註 } \\
\text { (總分) }\end{array}$ \\
\hline \multirow[t]{4}{*}{1.} & & 報告內容的豐富性 & & \\
\hline & & 報告內容的啟發性 & & \\
\hline & & 展示報告的表現 & & \\
\hline & & 組員的合作 & & \\
\hline \multirow[t]{4}{*}{2.} & & 報告內容的豐富性 & & \\
\hline & & 報告內容的啟發性 & & \\
\hline & & 展示報告的表現 & & \\
\hline & & 組員的合作 & & \\
\hline \multirow[t]{4}{*}{3.} & & 報告內容的豐富性 & & \\
\hline & & 報告內容的啟發性 & & \\
\hline & & 展示報告的表現 & & \\
\hline & & 組員的合作 & & \\
\hline
\end{tabular}




\begin{tabular}{|c|c|c|c|c|}
\hline 組別 & 專題題目 & 評審準則 & $\begin{array}{c}\text { 分數 } \\
\text { (最高 } 5 \text { 分) }\end{array}$ & $\begin{array}{l}\text { 備註 } \\
\text { (總分) }\end{array}$ \\
\hline \multirow[t]{4}{*}{4.} & & 報告內容的豐富性 & & \\
\hline & & 報告內容的啟發性 & & \\
\hline & & 展示報告的表現 & & \\
\hline & & 組員的合作 & & \\
\hline \multirow[t]{4}{*}{5.} & & 報告內容的豐富性 & & \\
\hline & & 報告內容的啟發性 & & \\
\hline & & 展示報告的表現 & & \\
\hline & & 組員的合作 & & \\
\hline \multirow[t]{4}{*}{6.} & & 報告內容的豐富性 & & \\
\hline & & 報告內容的啟發性 & & \\
\hline & & 展示報告的表現 & & \\
\hline & & 組員的合作 & & \\
\hline \multirow[t]{4}{*}{7.} & & 報告內容的豐富性 & & \\
\hline & & 報告內容的啟發性 & & \\
\hline & & 展示報告的表現 & & \\
\hline & & 組員的合作 & & \\
\hline
\end{tabular}




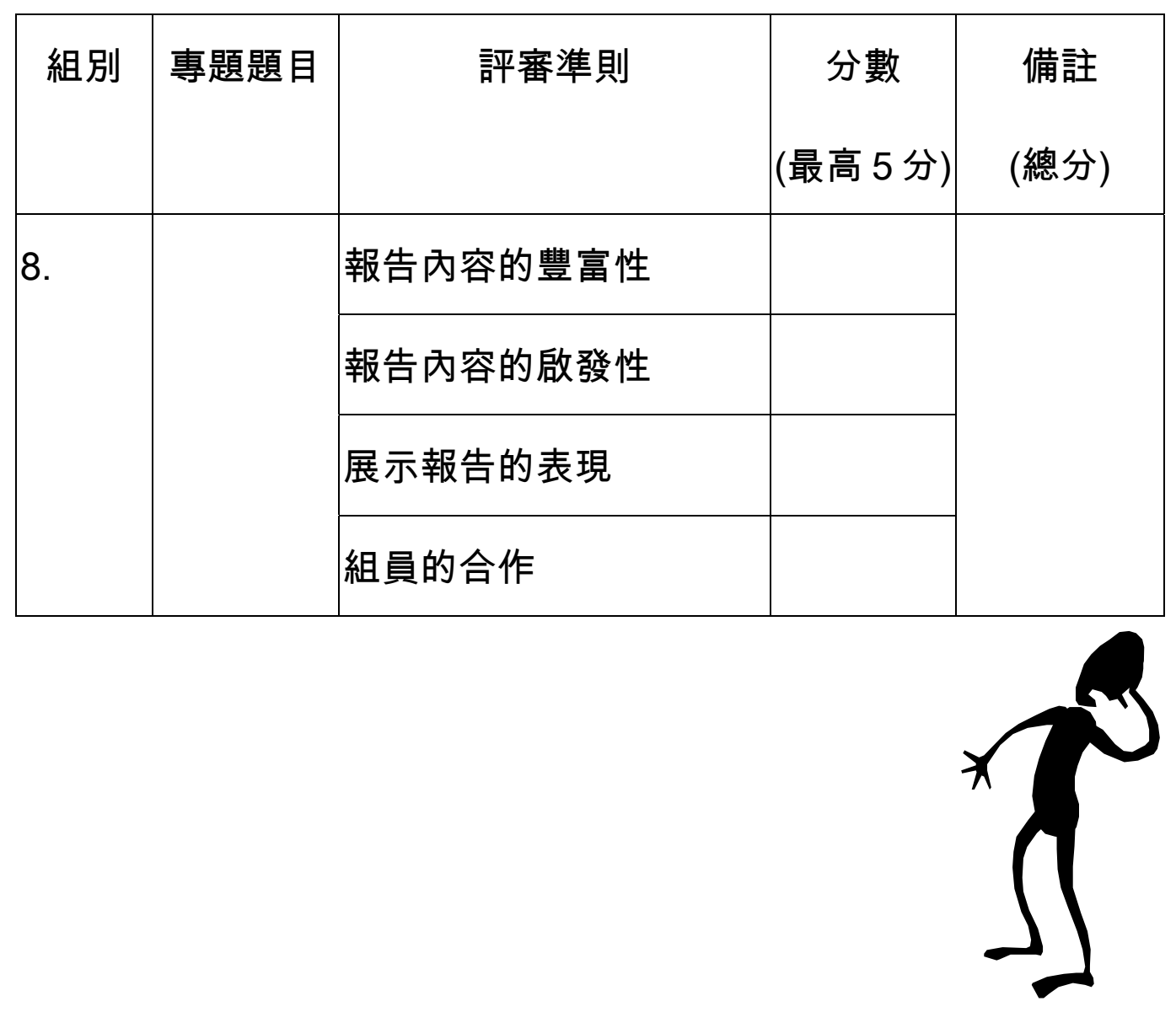




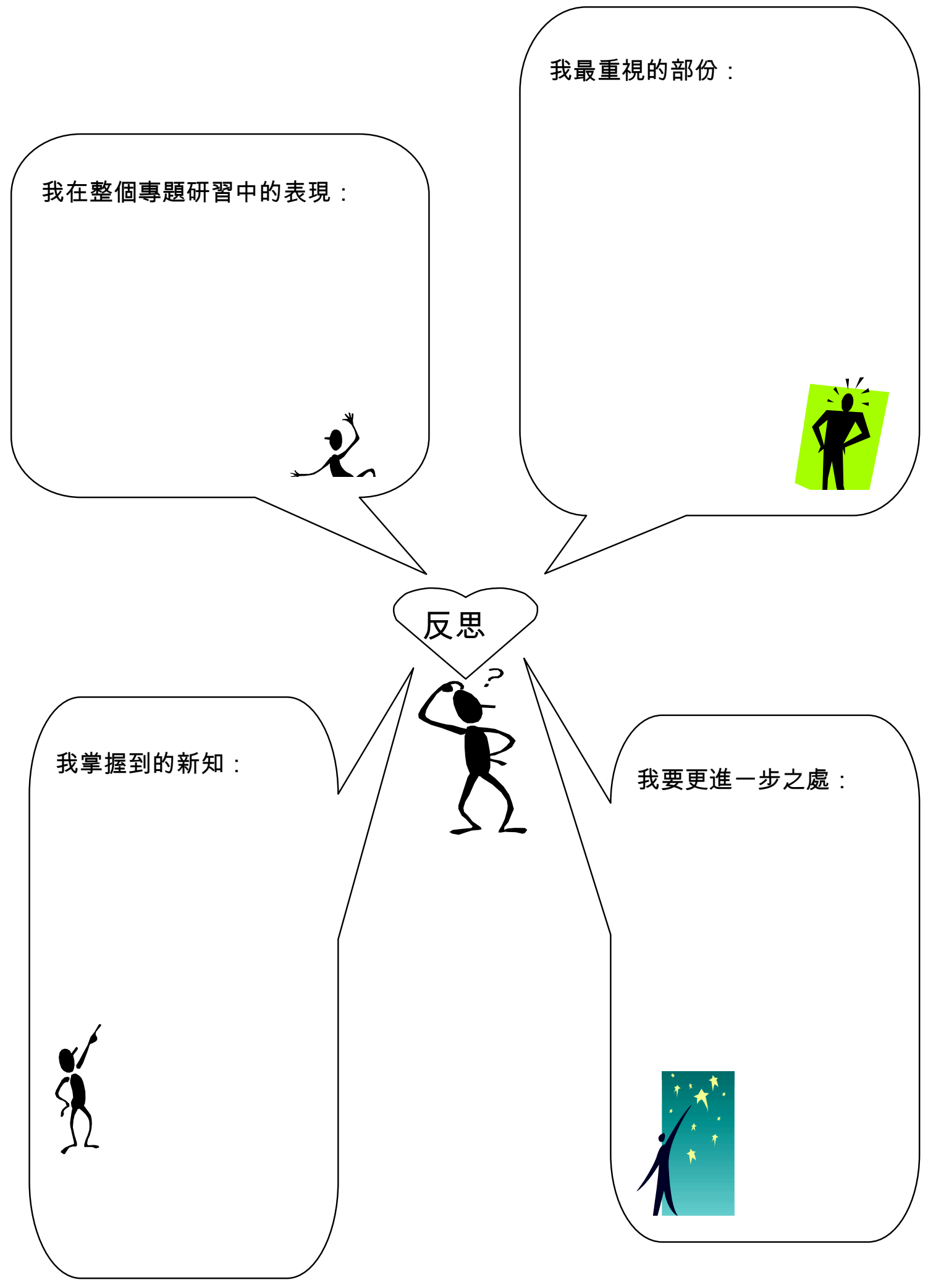


Reproduced with permission of the copyright owner. Further reproduction prohibited without permission. 